TOP MARKS FOR QUALITY PARKS

\author{
by \\ Jennifer Roth \\ BA, McMaster University, 2011
}

\begin{abstract}
A Major Research Paper
presented to Ryerson University
\end{abstract}

in partial fulfillment of the requirements for the degree of

\author{
Master of Planning \\ in \\ Urban Development
}

Toronto, Ontario, Canada, 2014

CJennifer Roth, 2014 


\section{Author's Declaration}

I hereby declare that I am the sole author of this major research paper. This is a true copy of the major research paper, including any required final revisions, as accepted by my examiners. I authorize Ryerson University to lend this major research paper to other institutions or individuals for the purpose of scholarly research I further authorize Ryerson University to reproduce this major research paper by photocopying or by other means, in total or in part, at the request of other institutions or individuals for the purpose of scholarly research. I understand that my major research paper may be made electronically available to the public. 


\title{
TOP MARKS FOR QUALITY PARKS
}

\author{
(C) Jennifer Roth, 2014 \\ Master of Planning \\ in \\ Urban Development \\ Ryerson University
}

\begin{abstract}
As the City of Toronto and the Greater Golden Horseshoe continue to become more densely populated resulting from the Provincial Growth Plan, increased stresses on existing parks spaces will occur due to overuse. The focus of this research is to evaluate Toronto's effectiveness in maintaining quality park spaces according to the Park's Plan (2013-2017) in the City through the trial of a Park Report Card that focuses on basic amenities in parks in the densest wards. The methodology was adapted from New York City's Park Report Card which involved the definition of basic amenities and a scoring scale for their functionality. The observed parks did not meet quality park standards according to the Parks Plan and a series of recommendations to improve the level of quality were provided.
\end{abstract}

Key Words: Park Report Card; Parks Plan; Quality Parks; Toronto. 


\section{Acknowledgements}

I would like to express my very great appreciation to my supervisor, Dr. Ron Pushchak, for his ongoing support throughout the development and production of this research project. His advice was central to the clarity of the report and the completion of this work. I wish to acknowledge the help of Dr. Pamela Robinson, the Graduate Director and my second reader, for providing valuable feedback. 


\section{Table of Contents}

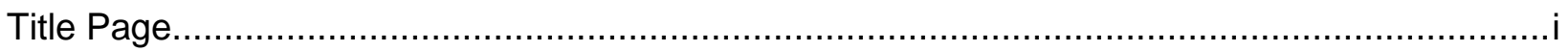

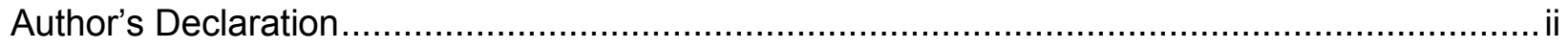

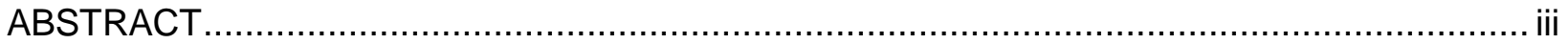

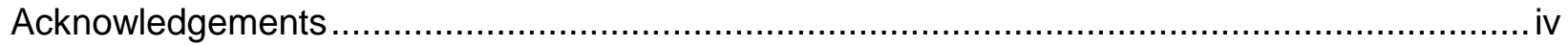

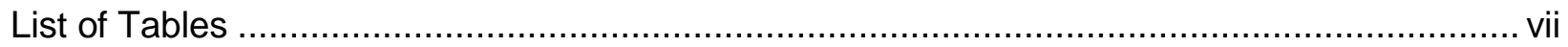

List of Appendices...................................................................................................... vii

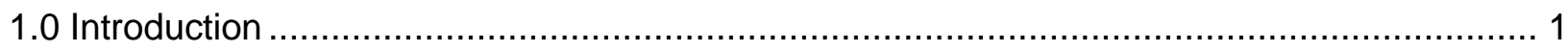

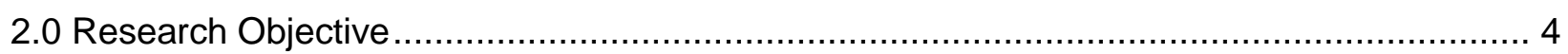

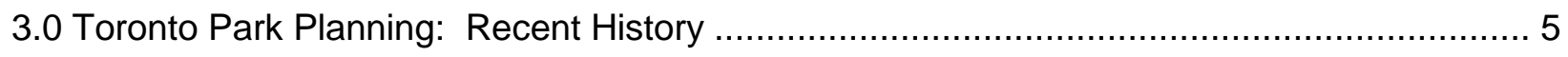

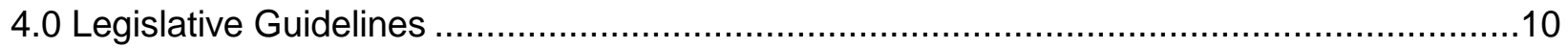

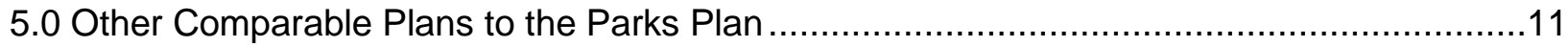

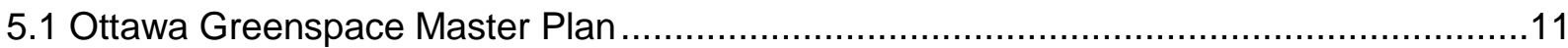

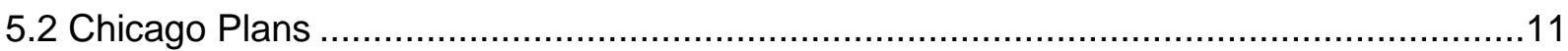

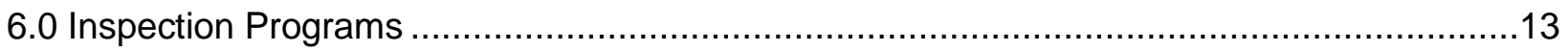

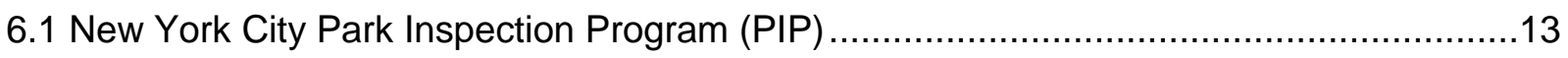

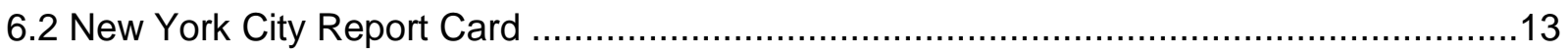

6.3 Toronto Park Inspection Program ……....................................................................

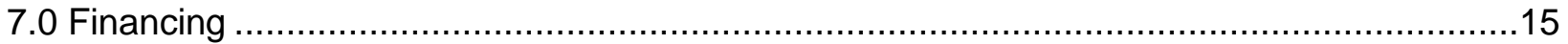

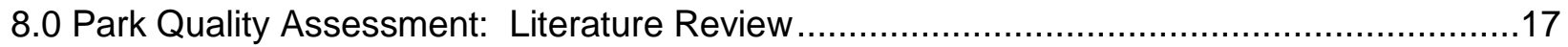

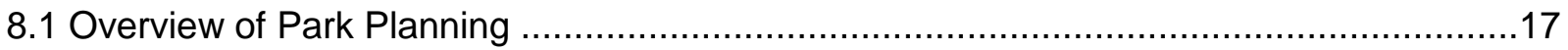

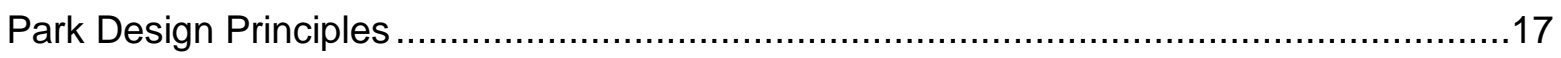

Park Carrying Capacity and Area Standards ............................................................18

Park Valuing and Community Engagement .................................................................19

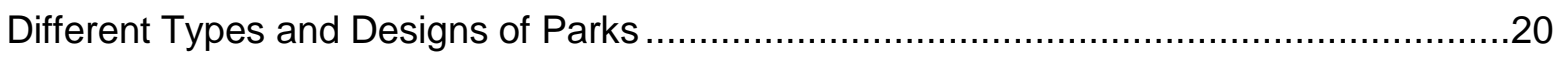

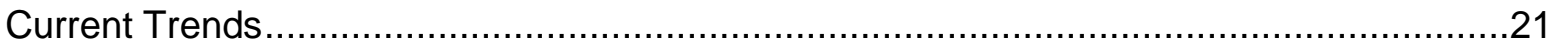

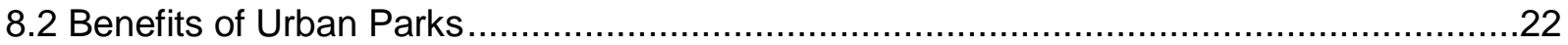

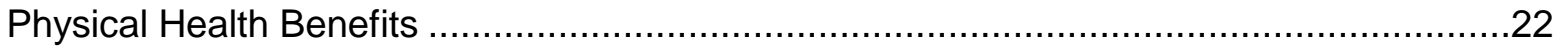

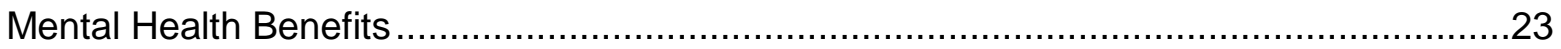

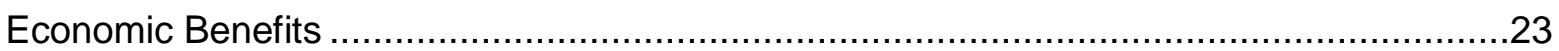

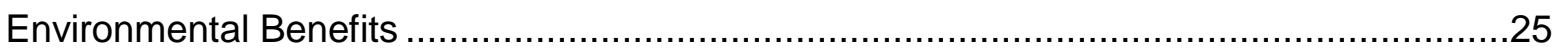

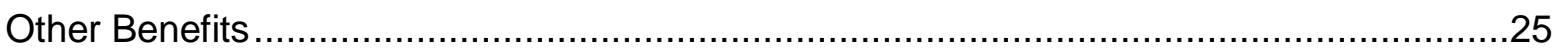

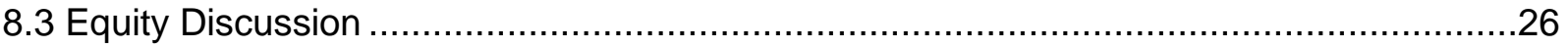




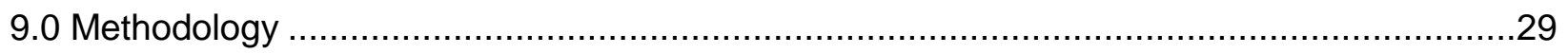

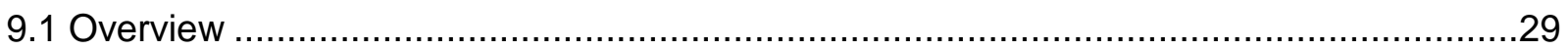

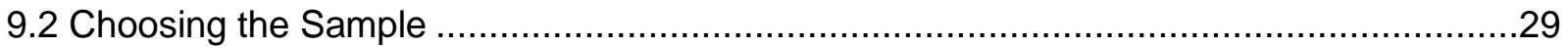

9.3 Choosing the Functional Criterion/Basic Amenities....................................................

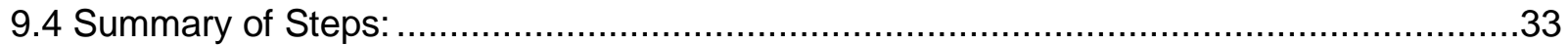

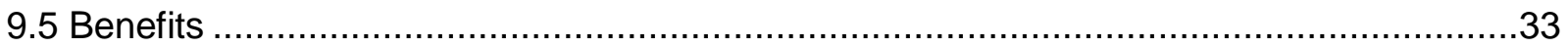

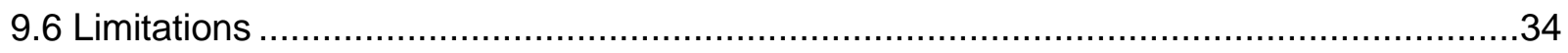

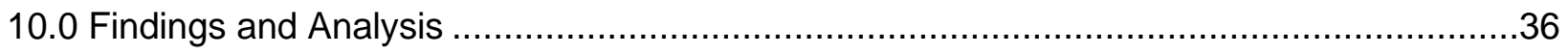

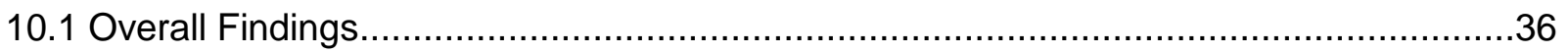

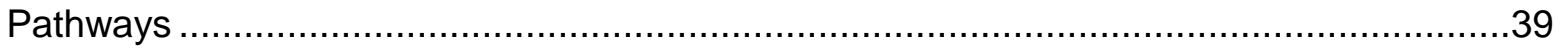

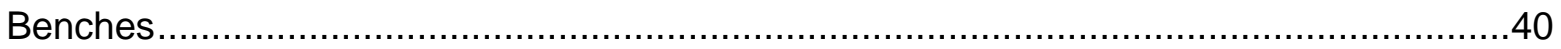

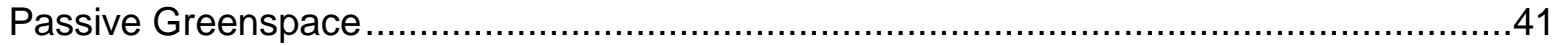

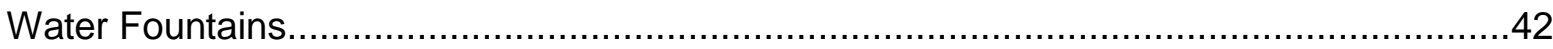

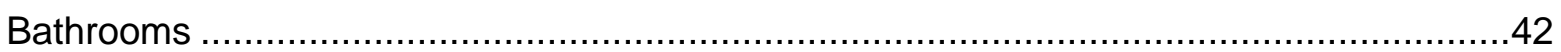

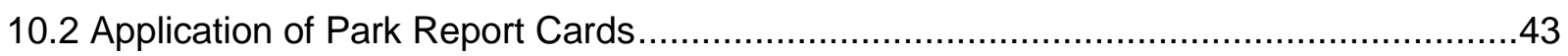

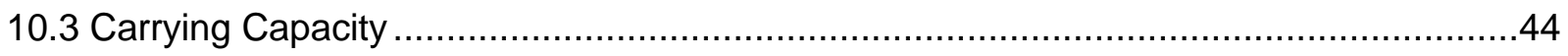

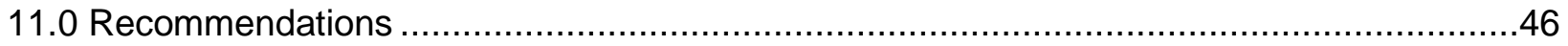

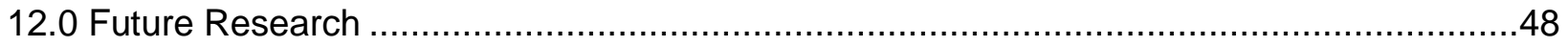

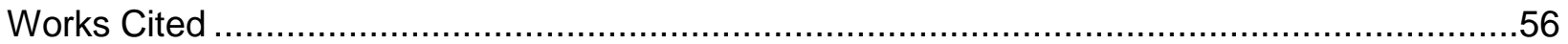

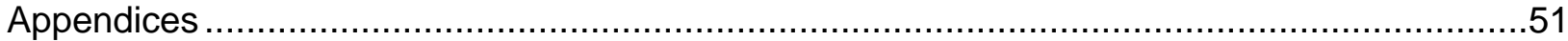

Appendix A - Toronto Park Categorization......................................................................

Appendix B - Park Sample and Ward Densities ...........................................................52

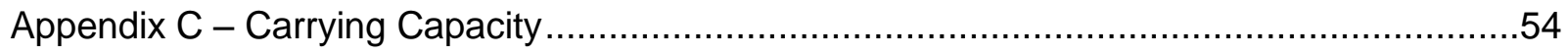

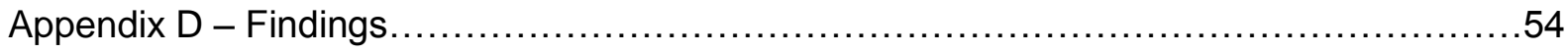




\section{List of Tables}

Table 1 - Total Park Space, North American Comparison

Table 2 - Total Park Space, District of Toronto Comparison

Table 3 - Basic Amenity Scores

Table 4 - Passive Greenspace

Table 5 - Bathroom

Table 6 - Water Fountain

Table 7 - Pathways

Table 8 - Sitting Areas

Table 9 - Conversion Chart

Table 10 - Park Grades 


\section{List of Appendices}

Appendix A - Toronto Park Categorization

Appendix B - Park Sample and Ward Density

Appendix C - Carrying Capacity Calculations

Appendix D - Findings Summary 


\subsection{Introduction}

Toronto's parks in dense downtown neighbourhoods are experiencing strain due to increased density. St. Michael's Urban HEART research report found that of Toronto's 140 neighbourhoods, 28 of them have greenspace shortages (St. Michaels, 2014). Combined, a lack of greenspace and diminishing park quality has made it necessary to ensure that an appropriate method for monitoring park's basic amenities is in place. This will ensure that the public is aware of the quality of their local parks. For clarification purposes, parks are "all publicly owned natural areas (forests, ravines, etc.) as well as playgrounds, playing fields, skateboarding parks, beaches, bike trails, river walks, cemeteries, hydro corridors, paved public squares, parkettes, and community gardens (Harvey, 2010, page 10)." According to the City of Toronto Parks Plan (2013-2017) (hereafter known as the Parks Plan) "quality means that a park is clean, safe, beautiful and well-maintained. A quality park also meets community needs and creates a sense of place (page 43)." This definition was developed based on public consultations that occurred prior to the development of the Parks Plan. This research focuses on using a Park Report Card to measure the level of cleanliness and maintenance in achieving two of the outlined components that makes up a quality park space.

It is imperative in maintaining park quality that an effective and established monitoring system is in place as Toronto and the Greater Golden Horseshoe Region continue to grow to meet Ontario Government mandated growth targets. It has never been more important to ensure that Toronto provides its residents with quality park spaces, especially in the densest urban areas where private greenspace access is limited. The newly implemented Parks Plan goes beyond attempting to counteract the $\$ 230$ million deficit in maintenance and repairs required by Parks, Forestry and Recreation (PFAR) and has a section entitled Quality of Parks that concentrates on making Toronto parks, quality parks. Since amalgamation, Toronto has struggled to update its park infrastructure, and as a result City parks have also languished. It is necessary to start moving park infrastructure forward to achieve quality parks as the population continues to rise and the capital deficit is expected to carry on increasing to $\$ 600$ million if no action is taken (Harvey, 2010). To ensure that park spaces are being maintained and repaired appropriately, a new method of park monitoring needs to be implemented to ensure that the community knows how well their local park is meeting the City-wide park standards.

Quality park spaces as outlined in Toronto's Parks Plan must be maintained despite growing and dense populations. To achieve quality spaces maintenance standards must be implemented equally across the city, and should be monitored and recorded. The Parks Plan 
firmly commits PFAR staff to producing and maintaining quality parks. The Parks Plan Mission aims to "enrich communities and lives by designing, building and operating quality parks (Parks Plan, 2013-2017, page ii)." PFAR must implement the Quality of Parks component of the Parks Plan as it is more difficult in dense urban environments to ensure that all residents have access to quality park spaces to gain the full variety of individual and community benefits. To ensure that parks are becoming and staying quality parks, it is necessary to monitor park spaces and make the findings public.

Long term planning is required to achieve functional and well designed parks. There are numerous benefits that make this type of government investment worthwhile. Generally there are health, economic and social benefits for residents (Pack and Schanuel, 2005). Benefits from parks will be explored more thoroughly below. When developing strategic plans, maintenance standards and monitoring programs such as the ones used in New York City, must be implemented to ensure that the goals in the plan are truly being met. Park monitoring or inspection programs are techniques used to measure if maintenance and repair standards are being achieved. Further explanation of the New York Park Inspection Program (PIPs) follows on page 13.

Park monitoring programs can also be used as a means to 'benchmark' a city's park space compared to parks within the city and to parks in other cities (Pack and Schanuel, 2005). Benchmarking occurs when an evaluation occurs by comparison to a defined standard and measures the quality of the feature of concern (Merriam-Webster, 2014). Benchmarking is a worthwhile endeavor as it will encourage PFAR to guarantee that parks are quality public spaces. For improved comprehension by the public, monitoring programs can be translated into park report cards providing letter grades denoting the level of quality of the space experienced by users. This has the potential to encourage more active participation by local community groups and more investment by the city if their local parks are receiving poor or failing grades. The research that has been conducted in Toronto takes the current parks inspection program further and develops a benchmarking system in the form of a park report card that is based on the New York City Park Report Card method that targets neighbourhoods under the duress of high density levels.

Park planning relies on an interdisciplinary team approach which has become the leading responsibility of landscape architects and planners (Christiansen, 1977). When planning parks, challenges exist similar to other planning experiences such as the inability to meet everyone's 
preferences (Rutledge, 1971). The functionality cannot be bypassed for beauty's sake as the "highest quality is a product which has no weaknesses" (Rutledge, 1971, page 53). This may seem like an unrealistic goal, but plausible plans with few weaknesses can be created for parks through interdisciplinary collaboration and public assistance. Striving not only for well designed and aesthetically pleasing park spaces, but for ones that are truly functional with high maintenance standards should be the main focus of park planners. It is important to understand that maintenance standards alter as the budget changes and to reflect changes in industry trends. These ongoing fluctuations must be taken into account when designing parks and maintenance standards to ensure that quality standards can always be achieved. To ensure that goals and maintenance standards are being met, park inspection programs and park report cards are required. As Alan Broadbent stated, "you can tell what a city thinks about itself from looking at the way it looks after its parks. Parks, principal among public spaces, are a telling face to the world" (Harvey, 2010). 


\subsection{Research Objective}

This research aims to investigate a park report card system that would measure the level of quality of park spaces in densely populated areas of the City. It will provide a benchmark for the parks sampled within the densest wards. It can be considered a small scale trial of the effectiveness of using a park report card method to compare parks and provide data for analysis. The research may be used as a confirmation of the current design and maintenance standards and may also provide information about areas that require improvements. The research will test the park report card method as a monitoring tool that can easily communicate and engage local communities while providing accurate information regarding the Quality of Parks as established by the Parks Plan.

The research that was conducted involved an adaptation of the New York City Park Report Card applied to a sample of parks in Toronto's densest wards to establish whether the parks are meeting the Quality of Park criteria as defined by the Parks Plan. The park report card method focused on basic amenities including; bathrooms, water fountains, benches, passive greenspace and pathways. The aim of using a park report card is to establish a monitoring tool to measure park quality that is public and easily comprehended as there currently is no established inspection program with public findings. 


\subsection{Toronto Park Planning: Recent History}

Before the Parks Plan was established, the Toronto Parks Renaissance Strategy was the existing park master plan. It was drafted in 2006 and was formulated as a "reinvestment program to align the City's parks, trails and physical assets with the social, economic and cultural needs of residents (Harvey, 2010)." A series of public consultations were held by a consultant from Urban Strategies who was hired to produce a preliminary report. Key findings as indicated by public consultation participants were issues about maintenance and lack of repairs being made in existing parks and the ongoing need for new parks in new and redeveloping neighbourhoods. It was recognized that the park planner's challenge is to find inventive ways to expand park space in already built-up areas. The report did not focus on a monitoring system or report card as a means of maintaining the quality of existing park spaces. Differences between user needs were identified with a central example of children and teenagers requiring different facilities (Harvey, 2010). Unfortunately, after the consultant filed their report, the Toronto Renaissance Strategy was not implemented. It was not until council approved the current Parks Plan that the information from the report, along with new information collected from public consultation, was used.

The current Parks Plan was established after council approved the development of a multi-year Parks Plan in February 2010. The origin of the Parks Plan was based on a recommendation from the Division's Our Common Ground report (PFAR, Staff report for action on the Parks Plan 2013-2017, 2013). Seven guiding principles were adopted in developing the Parks Plan (2013 2017) which included; parks and trails as city infrastructure, equitable access for all residents, nature in the city, placemaking, supporting a diversity of uses, community engagement and partnerships, and environmental goals and practices. Monitoring programs started to enter the language of the report; however, they were not made to be explicit or to be used as a form of community awareness and engagement. Following this, in June 2011, council approved a Stakeholder Consultation Strategy that produced four objectives; communicate and connect with users, preserve and promote nature, maintain quality parks and improve system planning (PFAR, 2013).

Most consultation participants were generally satisfied with the state of Toronto parks; however, as previously stated there were some concerns expressed about existing maintenance levels. Other concerns included availability of washrooms and improved washroom maintenance and the limited number of benches and water fountains. Larger Toronto parks provide basic amenities such as washrooms, benches and water fountains along with shade from mature 
trees which work together to allow parks to be the setting for social gatherings (Parks Plan, 2013-2017). Currently the City is developing a comprehensive approach to seating to encourage socialization in city parks which is centered on these basic amenities and permitting for social gatherings. Seating in parks predominately takes the form of benches but also includes picnic benches and objects that are not traditionally viewed as sitting areas such as a ledge around a flower planter.

An important aspect of the public's ability to use parks is the application of maintenance standards. City standards for maintenance aim to be equitable across the city and are influenced by factors such as user volume, intensity of use and neighbourhood density (Parks Plan, 2013-2017). For example, parks along the waterfront receive more tourists and therefore have a higher volume of use so they tend to be cleaned more frequently to ensure that the maintenance standards are met. By investing in and maintaining basic park amenities, the public will get higher quality park spaces as result. Despite not being made public at this time, there are monitoring systems in place that need to be made more explicit to increase public awareness of the quality of local parks.

The Parks Plan not only included initial stages of community engagement, but is intended to include the public throughout the five years of implementation. Closer relations with 'Friends of' groups are expected to encourage public ownership of local parks and to streamline the process from idea development to implementation stage. According to the Parks Plan 'Friends of' groups are local groups of volunteers from neighbourhoods surrounding parks in Toronto that independently work to maintain parks and jointly with the City to raise money to improve the specified park. In addition to public open houses, a reporting system for the public to use to raise maintenance and repair concerns has been developed and will be implemented by 2017 . The reporting method is, in essence an email and telephone hotline for community members to use if they see maintenance or repairs that need resolving in their parks. This method of reporting problems with parks can work in tandem with established but internal monitoring programs or updated programs to ensure that the highest park quality can be achieved.

The Parks Plan recognized that the City is growing and as a result city planners developed a park categorization system to provide a foundation for future service planning undertaken by the City. The park classification was developed as a means to help understand Toronto's park and trail system. It works as an administrative tool that helps to categorize the over 1,500 parks and 90 square kilometers of park space. The Parks Plan provides five classes of parks primarily 
based on the park's size and are as follows; parkette, neighhourhood park, community park, district park and city park. Park categorization can aid in park monitoring as parks of varying sizes will have different features. The City has the potential to incorporate park categorization and monitoring to assist in streamlining the inspection process and to improve the communication of the maintenance results to the public.

The total park space in Toronto compares favorably to other North American cities in acres per 1,000 residents. Table 1 demonstrates a comparison of the total park space of North American cities.

Table 1: Total Park Space, North American Comparison (Harvey, 2010)

\begin{tabular}{|l|l|}
\hline City & Total Park Space (acres/1000 residents) \\
\hline Toronto & 7.88 \\
\hline Montreal & 2.96 \\
\hline Chicago & 4.2 \\
\hline New York City & 4.6 \\
\hline San Francisco & 7.0 \\
\hline
\end{tabular}

Large concentrations of park space exist in the ravine systems in the east and west sections of the city. Despite high amounts of park space in Toronto, there is limited space in the more built up and dense sections of the city which is noted in Table 2 below.

Table 2: Total Park Space, District of Toronto Comparison (2006) (Harvey, 2010)

\begin{tabular}{|l|l|}
\hline District of Toronto & Total Park Space (acres/1000 residents) \\
\hline Scarborough & 11.81 \\
\hline Etobicoke & 10.13 \\
\hline East York & 7.56 \\
\hline North York & 7.43 \\
\hline York & 4.67 \\
\hline Toronto & 4.54 \\
\hline
\end{tabular}

Currently there are neighbourhoods in Toronto that are underserved by parks, but the City is attempting to expand park space by capitalizing on underutilized areas (Harvey, 2010). Recent additions to downtown park spaces include inventive solutions such as Underpass Park in the West Don Lands, a park built underneath Eastern Avenue as it crosses the Don River. This is 
an excellent example because it took formerly unused space beneath a bridge to create a park. The use of park dedication requirements by the City is a successful method for expanding park space in areas that are experiencing low access to parks. Despite this achievement, there will be a continuous need to upgrade and maintain existing parks to ensure that they meet the standards mandated in the Parks Plan. Knowing that the City possesses large tracts of park space, monitoring all of it can prove to be a challenge. It is necessary to implement a tool that can be used by the City to monitor all the spaces for maintenance and repairs as well as notify residents of the quality of their local park spaces.

Moving forward, PFAR will continue to implement the Parks Plan. The implementation of this strategic plan depends on both the operating and capital budget. PFAR will receive $4.3 \%$ of the approved operating budget for 2014 and $6 \%$ of the capital budget. The major source of funding is property tax and intergovernmental transfers (PFAR, 2014 Budget at a Glance, 2014). Despite some funding, many of the major initiatives in the Parks Plan have gone unfunded in 2014 including the area related to this research; of building and maintaining quality parks in dense urban neighbourhoods.

As previously stated, there is an extensive maintenance and repairs deficit of $\$ 230$ million in 2010 with an expected rise to $\$ 600$ million by 2018 . It is more imperative than ever that this become a political issue to ensure that parks receive the appropriate funding needed through both the capital and operating budgets. PFAR has developed their 2013-2021 capital budget to reflect their priority of providing park space in a state of good repair to keep pace with the growing and changing city. The approved 2014 capital budget will focus on reducing the State of Good Repair backlog by providing \$491.8 million (PFAR, 2014 Operating Budget Highlights , 2014).

As aforementioned, the Quality of Parks initiative outlined in the Parks Plan has not been provided with any funding in the 2014 City operating budget (PFAR, 2014 Operating Budget Highlights , 2014). It will be considered for funding in future budgets, but will require significant resources to fully implement. 2013 maintenance levels are being maintained at an incremental cost of $\$ 12.885$ million to bring the total operating budget for PFAR to $\$ 409.740$ million gross. All operating budget changes will focus on improving service levels to meet demographic changes and growing population needs over the coming years. 
Despite the lack of funding support, maintenance and repairs monitoring are ongoing but done with results only being known internally. A new method to work alongside or to replace the existing monitoring system needs to be implemented to support the increased concentrations of population in Toronto. A new method of monitoring needs to be implemented by PFAR as a means to raise public awareness, political concern and community engagement as the Parks Plan seeks future funding. 


\subsection{Legislative Guidelines}

The City of Toronto's Official Plan and the Province's Growth Plan have targeted the City to grow by half a million residents and a similar number of new jobs by 2031 . This accounts for almost $14 \%$ of the Greater Golden Horseshoe's growth (Harvey, 2010). As the City of Toronto continues to grow and become denser as a result of the Greenbelt preventing sprawl and density targets being achieved following the Growth Plan, it is becoming more vital to maintain quality park spaces and prevent overuse because parks provide the City and its residents with many benefits. Not only does the City preserve green and open space in parks in accordance with the Official Plan, but the Toronto Region Conservation Authority (TRCA) is in the process of finalizing its Living City Policies (LCP) which aim to combine the TRCA's legislative power with new policies that are focusing on development initiatives (TRCA, 2013). It is reassuring to see the regional authority of green and open space keeping pace with the growth of the city and region. 


\subsection{Other Comparable Plans to the Parks Plan}

\subsection{Ottawa Greenspace Master Plan}

The City of Ottawa developed its Greenspace Master Plan in 2006 which targets ways to preserve and expand the City's parks and forests. This plan recognizes the efforts of past councilors who assembled land along waterways and in communities before any houses were built (Greenspace Master Plan, 2006). It aims to preserve this legacy of greenspace as the population continues to grow. Ottawa is well positioned to enforce the Greenspace Master Plan as a result of amalgamation of 11 local municipalities and a regional government into 1 local municipality with more authority to streamline this process.

The major aspects of this plan are a greenspace inventory, the development of a greenspace network, expansions of greenspaces and increasing the quality of and access to greenspace. Quality greenspace is defined by the Ottawa Greenspace Master Plan (2006) as attractive, safe and well-designed, serving multiple needs of users while defining the unique identity of communities (page 27)." This definition is reflective of local values and aims to create spaces that residents need and enjoy. A complete inventory of City-owned parks was conducted which allowed for a more standard delivery and monitoring of parks in old and new neighbourhoods. The inventory also provides information on the contribution of parks to the larger greenspace network and areas where there is need for more parks. Updates to the parkland dedication bylaw will establish a standardized way to calculate the land requirements and the criteria needed to take cash in lieu of land dedication. When developing new communities, the park space must be linked to the existing greenspace network. Currently there is no monitoring tool listed in the Greenspace Master Plan, such as an inspection program or a park report card, to ensure that maintenance and repairs are completed and that the results can be made public.

\subsection{Chicago Plans}

The City of Chicago has several plans that include aggressive provisions to improve the quality and amount of green and park space. The Chicago City Space Plan (1998) envisions parks of "unmatched quality and beauty" in the downtown core (page 85). Parks in the city core are meant to be places for relaxation for downtown workers and visitors alike. This plan was a response to the growing density in Chicago's downtown which prompted a search for creative ways to improve and increase the amount of open space and parks. All district plans were made to reflect the initiatives outlined in the City Space Plan (1998). The central ideas of this plan focused on; expanding existing park and open space and creating new parks, creating a 
Riverwalk to act as a linear park, and on improving the access points to the open space. As part of the plan to expand green and open space, an inventory of vacant lots was conducted to demonstrate existing opportunities. The implementation of the Chicago City Space Plan (1998) focused on developing public-private partnerships and creating relationships with community groups and organizations. To ensure that the City Space Plan (1998) was meeting its outlined goals and objectives, several review and monitoring systems were implemented.

The Go To 2040 Plan is a comprehensive regional planning process focusing on creating a future for Chicago that is sustainable and aligns public policy and funding. The plan recognizes the system of parks that exists which adds to residents' quality of life and that there is currently inadequate access to parks for nearly half of the region's residents. As part of this plan, it is recommended to expand and improve the park system because of the personal benefits to the region's residents and the benefits to the regional economy (CMAP, Go To 2040, 2010). Parks are valued as green infrastructure that is central to the prosperity and livability of the region. The plan focuses on obtaining more park space in areas that are being built up to preserve the heritage of green openspace that was central to the 1909 Plan of Chicago that Daniel Burnham envisioned. This plan has comparable objectives to the Parks Plan to improve and expand park space where possible. The Go to 2040 Plan states that the region should monitor any programs implemented that result from the policies within the plan, but does not directly stipulate a method or potential funding source. Both of these are necessary to ensure that a monitoring or inspection program can be implemented effectively.

These comparisons provide an insight into how other park plans do not always include monitoring programs or having funding to implement them. Monitoring programs are essential to ensuring that maintenance standards are met and that quality park spaces are being sustained. None of the comparable park plans incorporated a means to use a monitoring program as a method to engage the public to improve awareness of park quality. 


\subsection{Inspection Programs}

Park inspection programs are monitoring systems that are necessary to ensure that plans to improve and expand parks are being achieved. Several programs will be explored which were central to the development of the method for the conducted research.

\subsection{New York City Park Inspection Program (PIP)}

The aim of this program is to measure performance by providing detailed inspections of New York City's parks and playgrounds. It is administered by the Operations and Management Planning division and provides information on the overall condition of New York City Parks as experienced by park users. Over 6,000 inspections are conducted each year by a group of trained inspectors who use hand-held electronic devices and digital cameras to track their observations (Parks N. , 2013). Park inspections examine cleanliness features, landscape features and structural features. Inspectors identify park elements that require maintenance and repairs which help to target limited funding to the areas of most need. Findings are made available online for the public and city officials.

\subsection{New York City Report Card}

The NYC PIP was developed in 2002 and was central to the development of the NYC Report Card method in 2007 which was developed by New Yorkers for Parks (NY4P). There are several major steps:

1. Selection of survey population

2. Identification and weighting of major service areas

3. Feature forms: structures of the survey instrument

4. Assignment of numerical scores

5. Conversion of numerical scores to letter grades

6. Conducting the survey

7. Comparison

8. Modifications

The survey selected parks between 1 and 20 acres in area which are classified as neighbourhood parks (DiPalermo, 2007). There were 123 neighbourhood parks chosen to be in the sample; however, not all of them were included (ie. parks undergoing capital improvements). Throughout the identification and weighting process, a group of community leaders and elected officials determined what the basic amenities, such as benches and water fountains, would be 
and their relative importance. A group of 30 park users were asked to rate the relative importance of each basic amenity which confirmed the weighting.

Four categories for evaluation were determined by NY4P staff and Ernst and Young, a statistical consultant to be included in the park report card inspections. The categories were; maintenance, structural integrity, safety and cleanliness. Focus groups were involved to provide feedback and rank the importance of each category in park spaces.

Field work was conducted by NY4P staff in June-August in 2006 after receiving uniform training on standards and handheld computers for recording findings. Once field work was completed, numerical scores were calculated for each major service area or basic amenity. To convert the numerical scores to letter grades, another focus group was held and its results are provided in the Table 9 in the Methodology, which was used to inform this research.

\subsection{Toronto Park Inspection Program}

Toronto's Park Inspection Program was developed in 2010 "to monitor the condition of Toronto's Parks (Parks Plan, 2013, page 46)" and was based on the New York Park Inspection Program. As part of the Parks Plan it was recommended that the current park inspection program in Toronto be updated to ensure that parks are safe, accessible and of high quality. Park employees in charge of operations and maintenance have and will continue to be central to the park inspection program as they continue to denote areas of concern regarding maintenance levels and repairs. This tool also provided information on types of successful service delivery and indicated quality. Safety concerns are followed up immediately and minor repairs are made within 48 hours (Parks Plan, 2013).

As the Parks Inspection Program continues to develop, it will reflect the new park's classification system as denoted in the Parks Plan. New inspection requirements will be added and the recording of observations will be made easier using mobile devices. The aim is to provide accurate and timely data reporting so that maintenance and repairs can occur quickly. This method is used internally to monitor parks and track data and the results are not made public. The park report card method being tested as part of this research aims to be a public resource denoting the quality of park spaces which is currently based on the functionality of basic amenities. 


\subsection{Financing}

As Olshansky (2003) states, "creating parks requires planning, citizen involvement and funding." However, there are budget restraints that exist and at times an unwilling political climate to invest in parks emerges. There are a series of policies that enforce park development including; Section 42 of the Planning Act that requires a portion of the development area to be given as a Parkland Dedication or cash in lieu (Parks Levy Fee), and Section 37 of the Planning Act that provides for an exchange of increased height or density for a public benefit which includes park space. Transparency and accountability of all funds collected through Section 42 and Section 37 must be achieved to allow the public to benefit from the legislation that has been outlined on their behalf. Development charges are not a plausible way to expand land required for park space according to section 4 in the Development Charges Act, 1997. Ongoing funding needs to be secured to ensure that parks can be maintained and become quality spaces through the use of monitoring programs which are central to ensuring that this can occur. Funding for park inspection programs is invaluable and must expand as population density increases and the amount of park space in Toronto expands.

Harvey (2010) says that more creative ways to gain funding for parks should and can be obtained. Corporate donations should be encouraged and can be done after a revision to the no-naming policy of the City. Selling naming rights for parks and park facilities can be used to increase the funding opportunities in developing new parks and improving existing parks. Improved relationships with 'Friends of' groups who have fundraising opportunities can enhance the community engagement and have funded parks that reflect what users really want. Park improvement areas can be developed to "facilitate individual and corporate funding for local parks (Harvey, 2010, page 7)." Private donations normally cover capital costs, but there is little improvement found in obtaining donations to cover operating costs of park maintenance which would include monitoring programs.

The PFAR 2014 recommended operating budget is $\$ 409.740$ million gross which is an increase in the operating budget of $\$ 12.888$ million to continue the 2013 maintenance levels (PFAR, Toronto 2014 Budget, 2014). Of the operating budget, parks receive $34 \%$ of the total allotted amount. There are a variety of government agencies such as the TRCA, Waterfront Toronto, Rouge National Park, who work alongside PFAR to create quality park spaces in Toronto. As stated, there are a number of ways that parks are funded from new development. An excellent example is Canoe Landing, which is a new 10 acre park and open space facility that was built by the developer as part of the City Park development in Toronto (Harvey, 2010). 
For smaller sites, it is not as easy to obtain park space, so cash in lieu is obtained at a rate of $5 \%$ for residential development and $2 \%$ for commercial development. The funds from this parkland levy are placed in the City's Parkland Acquisition Reserve Fund (PARF) and are spent equally in four ways: $25 \%$ for land acquisition in the local area, 25\% for land acquisition across the city, $25 \%$ for development and upgrades to existing parks in the local area and $25 \%$ for development and upgrades to existing parks across the City (Harvey, 2010). PARF spending is determined at the same time as the budget is finalized by council.

The section 37 public benefits from increased height and density allowances for developers are dependent on the local councilors' negotiating abilities. Questions of accountability and transparency in these negotiations have been raised by the development community and the public, and the City developed guidelines to rectify this deficit in 2007. Many local park improvements and new parks have been obtained using Section 37 benefits in neighbourhoods like the Queen West Triangle and Fort York.

Land Acquisition for Source Water Protection is a program that purchases land to protect the City's drinking water supply. Funding for this program is derived from Toronto Water and has been successful in obtaining new park land. Through this acquisition program, 68 acres of land were added to Rouge Park (Harvey, 2010). This is an excellent method to expand green and open space within urban boundaries while promoting sustainable environmental treatment.

There are a number of funding tools that are available to increase and improve existing parks in Toronto that should include the provision of funding for a monitoring system with publicly accessible results. The level of effectiveness of some of these funding tools needs to be enhanced with particular emphasis on gaining more private donations and building partnerships. Park levies must be used to gain more park space or improve existing parks and the transparency of this process must be increased; however this is beyond the scope of this research. Quality park spaces must be central to the development, redevelopment and ongoing maintenance of parks and their funding sources. Overall, park funding is central to supporting park monitoring programs that promote park quality and is unfortunately outside of this research's scope. 


\subsection{Park Quality Assessment: Literature Review}

There is much research focusing on park planning and its many components as "parks are, in fact, a vital element of city building, one of the basic pieces of infrastructure needed to make cities fit for human habitation (Olshansky, 2003, page 318)." Within this literature review, broad industry movements and history have been explored. From this an overview of different principles, standards, valuing and trends of parks, the categorization of parks, the benefits of parks, and a discussion of equity have been included to inform the research that has been conducted. The literature has influenced the approach taken in developing the checklist criteria for the proposed monitoring system and the focus on basic amenities instead of aesthetic components of parks.

\subsection{Overview of Park Planning}

Park planning has a long history and many different design progressions. Andrew Wright Crawford was an early park planner in Philadelphia who realized the need to bring parks to the people as "parks that are not accessible easily and cheaply are useless (page 289)." Frederick Olmstead agreed that all Americans should have access to parks and greenspace since prior in European Cities, parks had been a privilege for people who could afford to pay for them (Garvin, 2000). Knowing the benefits of parks and the positive experiences of the City Beautiful and City Healthful movements experienced in Bourneville, England, of lower death rates and their correlation with a higher number of parks, Wright sought to bring excellent park design standards to North America. He argued that parks must be oriented to the street and allow natural topography to influence the placement of park features (Crawford, 1910).

\section{Park Design Principles}

Garvin (2000) found that even in cities with a large amount of green space, parks must be located in areas where residents can access them. Mattocks (1937) outlined seven general guiding principles of an ideal park plan to aid in providing parks in built up areas and not in outlying areas so as to increase the ease of access for residents (Crawford, 1910; Moeller, 1965). The seven principles for designing park spaces are; use, planning, artistic unity, balance, scale, style, and the use of plantings. Planners must determine the use of the park and should be influenced by the surrounding environment's zoning and population density. The plan should be reflective of the park's purpose and must balance artistic and practical necessities (Mattocks, 1937). There needs to be harmony and artistic unity and a balance 
between formal and natural areas. Scale, style of design and the use of plantings must all be reflective of the setting of the surrounding architecture.

Mattocks (1937) viewed park spaces as a natural continuation of the city and argued that they must be planned with equal force. Ensuring that park planning principles are used effectively to bring park spaces to people so that they are easily accessible has been a common practice within this field of study. Park spaces must be viewed as an imperative part of the city and be planned using strong design principles to ensure that quality park spaces prevail. Knowing the importance of park spaces within cities it is important to ensure that their quality is maintained as cities grow and become denser through the application of monitoring and inspection programs.

\section{Park Carrying Capacity and Area Standards}

Overuse of park spaces can lead to low quality parks. To prevent overuse, the practice of calculating a carrying capacity or design load, when planning parks and developing additional park spaces, has been used. Carrying capacity or 'design load' is "the optimum number of people...that an area or facility has been designed to physically hold (Christiansen, 1977)." It is important to calculate the carrying capacity of a park that is in an area of heavy use so that it will not deteriorate and park planners will recognize when another park is required so the quality of a park space is maintained (Fogg, 1975). Therefore, a major component of determining the required park space is population density (Moeller, 1965). These calculations are integral to park planning in dense urban spaces. Park inspection programs can aid in carrying capacity calculations to ensure that park quality is maintained as cities continue to become denser.

In 1914 Charles Downing, a landscape architect for the New York State Department of Parks calculated that a city of 100,000 residents would require 1,500 acres of park space. This was to be divided amongst parks of differing sizes, from the city park scale to local playgrounds. At the time about a quarter of American cities met this standard with some far exceeding it. Downing went on to argue that, for cities with populations of 500,000 or less, the standard of 1 acre per 200 residents be used and for cities with populations over 1 million residents, the standard of 2 acres per 300 residents should be used (Moeller, 1965). These area standards can aid in calculating the carrying capacity of parks and can assist cities in recognizing when more park land is required.

A related concept is the social carrying capacity, which is the "degree of satisfaction of users" (Yapp and Barrow, 1979, page 199). This is an important factor that must be incorporated into 
park planning procedures as park users must be satisfied with the provided park spaces; otherwise their quality may be considered lower. Public engagement is central to having a high degree of satisfaction among park users. The proposed use of a park report card to make the quality of park spaces known to the public can be viewed as a form of public engagement. The report card will notify residents of the quality of their park and will encourage the public to become active in improving their local parks. This can be done in a series of ways including lobbying political bodies, becoming a member of a 'Friends of' group and fundraising (Harvey, 2010).

\section{Park Valuing and Community Engagement}

As the recognition of the need for more park land grew, it corresponded to the increased value being placed on parks by the public. Francis (1987) found that there was a gap between city employees' and users of parks' valuations of park spaces; with the public valuing parks higher than City staff (Loukaitou-Sideris, 1995). Public support for urban park space has continued to grow as parks provide many different recreational activities and improve the quality of life of residents (Salazar and Menendez, 2005). Parks continue to gain value and recognition as a public resource and as an imperative component of the public realm, even by non-users. City employees have over time recognized the growing importance of parks to the public and as a result the designs have become more reflective of how people choose to spend their time in parks and not as focused on past design principles (Page et al., 1994).

Park planners must assess community needs appropriately to give the public what they need and value in park spaces. In the past, park designs and plans would not have been as reflective of the park user groups and their ideals as they are currently. It is extremely challenging to design park spaces in multi-ethnic areas as park designs and plans should reflect the values and specific needs of a variety of ethnic groups and allow for the co-existence of all ethnic groups in a community (Loukaitou-Sideris, 1995). To successfully meet different user needs, park planners must seek community input. As a part of that process, park planners must learn to efficiently allocate and prioritize community needs as there are limited resources (Olshanksy, 2003; Page et al., 1994). As well, park planners will have to meet community needs within park budget constraints.

Park master plans can be developed to reflect the community's needs and goals as a basis for action plans that focus on implementation (Pack and Schanuel, 2005). Park master plans must also include monitoring and inspection programs to ensure that the quality of parks is 
continuously achieved as cities continue to grow. As part of the implementation and monitoring processes, there is an ongoing struggle to find cost effective ways to deliver the park services required to meet the variety of public needs. Despite this financial obstacle, parks need to remain accessible public goods that do not have user fees attached to them as they contribute to the wider public good (Page et al., 1994). Because user fees are a regressive tax, they would limit the equitable distribution of park space benefits.

\section{Different Types and Designs of Parks}

There are different types of parks that can be classified in a variety of ways and can be distinguished by their different features. Classification systems have been developed based on park size, park use, amenities present, location, and recreation uses. Moeller (1965) outlined a park classification method that has three categories: neighbourhood parks, community parks and major parks. Categorization of parks aids in the monitoring of park spaces. As there are varying sizes of park spaces, different degrees of inspection and time investments are required.

Passive and active recreation opportunities for locals are a priority of neighbourhood parks of varying sizes. Community park spaces must be accessible by public transit and be large enough to serve several neighbourhoods. Major parks provide city residents with connections to nature and provide unique recreation options (Moeller, 1965). This classification varies based on size of the park space and reflects the types of features and uses contained within.

Park features and activities are reflective of the type of users of the park space. Kemperman and Timmermans (2006) found a correlation between different age groups and the type of park space that is preferred. As a means to accommodate most user needs, a three division functional layout was designed. There are areas of active recreation, a naturalized buffer area and an area for passive recreation, all of which occur in varying ratios of size of each area that is reflective of local need (Mattocks, 1937). This park design layout allows for a variety of users to be content with the same park space despite using it differently. Applying a monitoring system that focuses on functionality of basic amenities in parks instead of one focusing on aesthetics will ensure that a greater number of users' needs are met.

There are various types of parks that have emerged in the field of park planning including but not limited to; the Pleasure Ground, the Reform Park, the Recreation Facility, the Open Space System and the Sustainable Park. Cranz and Boland's (2004) research focused on the emergence of the Sustainable Park in 1990 which was reflective of growing ecological concerns (Jim and Chen, 2003). The three main attributes of the sustainable park were self-sufficiency of 
material resources and maintenance, its ability to resolve larger urban problems (ie. storm water storage) and its creation of new aesthetic urban standards. Parks are now being designed with more sustainable features to help promote ecological awareness within urban centers and can reduce the level of maintenance that is required.

As Rutledge (1971) stated, planners and landscape architects must design with purpose. Good quality park designs must be functional as well as aesthetically pleasing to meet community needs. For example, durable surface treatments are required along paths where there is constant foot traffic. This will ensure that paths remain intact despite heavy amounts of use, which contributes to quality park spaces. Challenges arise when a community has different opinions about how a park space should be designed. Some individuals would disagree that a durable material should be used for paths suggesting that a park should be naturalized. This is a major challenge for park planners since they will be faced with the task of meeting everyone's preferences in designing new parks and redesigning existing parks. City-specific standards are used to aid park planners in trying to meet diverse park needs and wants but they should be viewed as guides and can be modified as required (Rutledge, 1971).

\section{Current Trends}

There are a variety of factors that influence park planning trends. There are current park trends that are reflective of community wants, needs and values. For example, mobile park furniture is a newer innovation that is being used when designing park spaces as it allows users to locate seating in areas that they prefer instead of in mandated locations (Loukaitou-Sideris, 1995). Toronto's current Parks Plan reflects such new industry trends. Not only does PFAR's planning require effective community engagement, it also requires a comprehensive analysis of citywide land uses (Loukaitou-Sideris, 1995). This allows planners to be strategic and allows for the most effective organization of land uses.

Current trends in park planning reflect demographic changes. Newcomers and aging populations alter the types of activity that determine the use of parks. An example of changing demographics is seen in California where there are changes recognized in recreation patterns due to aging populations in parks which are reflected in changing trends in the use of parks (Parks C. S., 2005). Another example is that Caucasians are the most represented and African Americans are the most underrepresented ethnic group in outdoor recreation in parks and open space in California. As well, immigrants tend to recreate together as a way to preserve cultural heritage and tradition (Parks, 2005). Trends vary within ethnic groups as well. The California 
Park and Recreation Trends (2005) analysed local trends of demographic changes and the corresponding changes in use of parks. For example, it was discovered that large immigrant groups use parks as a social gathering space (California State Parks, 2005). Park master plans ensure that trends are being implemented as well as ensuring there are appropriate funding tools in place to meet all user needs (Pack and Schanuel, 2005).

There is limited literature regarding the use and application of park inspection programs as a tool to ensure the quality of park spaces is maintained or as a means of community engagement. Moving forward, the use of a park monitoring system such as the New York City Park Report Card will become a more prominent trend as a means of communicating how well parks are achieving city standards.

\subsection{Benefits of Urban Parks}

There are extensive benefits to parks in urban settings which are well researched within the literature. Benefits vary widely and include but are not limited to; physical and mental health benefits, economic benefits, social benefits and environmental benefits. Monitoring programs can ensure that parks are maintained appropriately and all park benefits can be publicly received even in densely populated cities. As this research is so widely conducted, only some of the most current researchers have been included.

\section{Physical Health Benefits}

One of the most recognized benefits of parks is that they encourage recreational uses that increase levels of activity outdoors and have positive physical health implications that improve quality of life of residents (Godbey et al., 2005; Nowak et al., 1998; Petros and Costa, 2011; Salazar and Menendez, 2005). The National Recreation and Parks Association (NRPA) (2010) and Frumkin (2003) both found that parks provide a necessary venue to maintain good physical health. Parks are increasing in their importance as there is a growing movement to counteract obesity given that 1 in 3 American children are overweight and 1 in 6 are obese. Weight loss can result in a lower chance of getting diabetes which could have longterm healthcare cost implications (Harvey, 2010). Therefore, positive health outcomes can be the result of access to quality park space.

Additionally, seniors benefit from greenspace in parks as it has been reported that they have improved functionality and live longer (NRPA, 2010). Frumkin (2003) found that basic amenities like good lighting, toilets, water fountains and well-maintained paths lead to higher levels of physical activity in both younger and more senior demographics. It is necessary to correlate the 
features found in parks with the users of park spaces because parks are positioned as a health and wellness feature of cities (Godbey et al., 2005). Providing basic amenities that are well maintained is necessary in achieving positive physical health benefits. The application of a monitoring program to measure the quality of basic amenities can help achieve community physical health benefits by providing data on how well park standards are being met.

\section{Mental Health Benefits}

Not only do parks benefit physical health, but there are correlations between parks and mental health benefits (Nowak et al. 1998; Petros and Costa, 2011). There is a growing body of research that confirms contact with or awareness of nature improves the quality of life of residents in urban spaces (Kaplan, 1998; Hartig, 1991; Hartig 2004 and Ulrich, 1979). Parks can provide the necessary contact with nature to ensure that city residents can achieve a high quality of life and improved mental health. Links between low nature access and high levels of anxiety, attention deficit hyperactivity disorder (ADHD), depression and stress were observed in a study conducted by scientists in the Netherlands looking at the prevalence of anxiety disorders in 345,000 adults (NRPA, 2010). Findings demonstrated that there is a correlation between increased anxiety disorders in adults in residential areas that do not have access to greenspace in parks. Therefore, by improving access to parks in residential areas, a reduction of the levels of anxiety disorders and other mental health challenges may occur. Findings such as these indicate the potential for health industry savings.

Parks provide greenspace in urban areas that act as nodes of stress relief and provide mental health respite. Not only are there stress relief benefits, but there are links between nature and improved cognitive functioning and impulse control (NRPA, 2010). The emotions and feelings of well-being that are evoked in park spaces are thought to be important contributors to mental health (Chiesura, 2004). Parks are an important component in improving and maintaining positive mental health outcomes, as depression was diagnosed in $33 \%$ more adults in neighbourhoods with low access to greenspace in the same controlled study from the Netherlands (NRPA, 2010). Therefore, those residents who have access to parks are at an advantage compared to residents with low access to parks because they have improved cognitive function and decreased levels of mental health diagnoses.

\section{Economic Benefits}

Potential savings in the health industry are not the only positive economic impacts that parks provide. There are also direct economic benefits to local governments as larger parks tend to 
act as tourist attractions (Harvey, 2010; NRPA, 2010). Revenue from tourists increases total revenues and benefit local governments. Local governments can benefit indirectly from park investment as well through an increase in property tax revenue from surrounding properties which is a concept that has been extensively researched (Salazar and Menendez, 2005).

Building from Olmstead's findings of the increase in property values that are adjacent to parks, Kitchen and Hendon (1967) conducted a cost-benefit analysis of land values of properties adjacent to parks (Crompton, 2001). They discovered that that the further a property was from a park, the lower the value. Overall, they noted the market relationship of property value and the distance to a park. Pack and Schanuel (2005) confirmed this finding as they found that property values increased with increasing proximity to parks. However, they realized that the type of use within the park may affect property values. For example, active recreation opportunities like basketball courts may deter some investors due to associated noise levels. Pack and Schaunel (2005) suggest that park design can counteract this finding if passive recreation areas border surrounding properties and the active recreation areas are located in spaces that will have minimal effect. Therefore, proximity to parks increases property values and property tax revenues benefiting home and business owners as well as the local government.

Parks can trigger revitalization and development of surrounding properties in urban areas (pack and Schanuel, 2005). An excellent recent example of this is the Highline in New York City. The former elevated freight line was converted into a linear trail and park system and, as a result, there has been growth in development surrounding it (NRPA, 2011). Parks spurring development in surrounding neighbourhoods will increase property values and the expected property tax which will benefit local governments. Cortes (2008) found that the $\$ 1.5$ billion construction investment in the Highline is expected to increase residential and business property values by $10-15 \%$. This will result in higher property tax revenues for New York City. Similar experiences are expected to occur in other cities that invest in their parks, even at a smaller scale.

Knowing the number of economic benefits that parks can provide, it is necessary that the quality of parks is maintained as increasing use and strain is placed on them resulting from increased population densities in cities. If parks fell to disrepair and were seen as blighted and unsafe areas, this would have the opposite effect to the above findings where parks increase properties 
values. To ensure that parks are being maintained at a high level of quality, park inspection programs are necessary as they enforce city standards and ensure that parks can provide positive economic benefits.

\section{Environmental Benefits}

Parks provide cities with much needed green space and act as an escape for residents from concrete. They also provide dwelling space for wildlife living in the city as well as many climate benefits. For example, Rouge Park in Toronto is large enough to provide a lot of viable habitat for wildlife. Not only do parks provide wildlife with respite, but they also reduce the heat island effect in cities and provide benefits to the water system. A park's greenspace can improve water quality if there are wetlands to assist in water purification (Harvey, 2010). As well, parks can act as areas of water storage which can reduce run-off and flooding in the event of storms or winter melts. Both have the potential to reduce stress on local treatment plants.

Frederick Olmstead called New York City's Central Park the "lungs of the city" which refers to the air quality benefits that a park provides for citizens. Greenspaces in urban centres provide invaluable benefits as they remove air pollution, store carbon and reduce temperature increases resulting from asphalt and concrete (Salazar and Menendez, 2005). Decreases in carbon dioxide and pollution may have a positive effect on respiratory illness levels.

Overall, environmental benefits of park spaces can be viewed as part of the sustainable renovation of cities to improve their ability to adjust to climate change. Ensuring that parks are maintained to provide these environmental benefits is necessary especially during times of population growth and increased urban density. This can be accomplished through programs that guarantee the ongoing inspection of park spaces such as the NYC park report card. Maintaining passive greenspace and naturalized areas at their highest level of quality will ensure the maximum benefit can be provided for the public.

\section{Other Benefits}

There are other benefits that are less explored but are still positive outcomes resulting from parks in urban centres. Parks provide space for social gatherings and interactions with neighbours which decrease loneliness, crime and aggression (NRPA, 2010). Communities that invest in their parks for social purposes are investing in their youth as well. Parks provide safe, natural spaces for youth to develop into strong and contributing community members (NRPA, 2010). Parks provide spaces for urban agriculture which is an educational tool as well as a means to improve food security (Harvey, 2010). As parks provide so many benefits to 
residents, they are a sought after feature when individuals are choosing where to live. Therefore, cities must consider this as they expand, grow and become denser and planners should be able to provide parks to attract new residents (Harvey, 2010). Pack and Schanuel (2005) note that when St. Louis was experiencing a housing boom its government created a comprehensive park plan to ensure that there was enough park space for all residents to receive equal benefit. Parks require strategic planning to capture their health, economic, environmental and other benefits.

It is necessary to ensure that all the above benefits are being presented to city residents in their parks despite growing urban populations. To ensure that this is occurring, quality park spaces must be achieved through the use of park master plans such as the Parks Plan. Plans such as this must ensure that there is funding secured in the operating budget to implement all policies within the plan including monitoring or inspection programs. Monitoring programs can ensure that parks are maintained appropriately which will ensure that parks can provide the greatest community benefits.

\subsection{Equity Discussion}

As outlined above there are numerous benefits to park spaces in urban areas. There are also researchers who explicitly state that access to parks must be equitable due to the need to share the benefits that result. City Council stated that one of its central principles in developing the Parks Plan was to ensure "equitable access for all residents (PFAR, 2013, page 4)." This was reiterated again in the 2014 operating budget (PFAR, Toronto 2014 Budget, 2014). Ongoing pressure to increase the equitable distribution of and ease of access to parks by the City's residents must also be extended to equitable park quality. All residents should have access to Quality Parks and not just individuals who could afford them.

Currently the Toronto maintenance standards are equal across the City and, despite some parks receiving more use than others, all parks are supposed to be maintained equally. To ensure that all parks are equally maintained despite growing strains caused by density, citywide programs that provide ongoing monitoring must be implemented. A park's ability to meet park standards as measured by inspections programs must be made public to allow the community to recognize discrepancies in park maintenance. The results must be conveyed in a way that is easily interpreted by the public so that there will be no barriers. The New York City Park Report Card provides an interesting opportunity to convey park standards in a grade. 
Historically, park planners used to situate parks and recreation facilities on the edge of cities or in wealthy areas. Moving forward, park spaces are being more equitably distributed as parks are growing in importance, especially in dense urban areas as there is limited access to private greenspace areas (Harvey, 2010). In particular areas, of low income and high density have a higher need for parks as there is less of a financial opportunity to seek out greenspace and nature outside of local parks (Moeller, 1965). Those individuals who cannot afford private greenspace should not be penalized, but should be provided with access to quality parks. The benefits that individuals receive from parks, such as physical and mental health benefits must be equally distributed across the city.

Deakin (1999) states that planners need to promote equity, fairness and justice within the city. Therefore park planning in the city must also promote equity, fairness and justice which encourages citizen equality as they access park spaces. Having equitable access to parks will aid a city in becoming more Just, as described by Fainstein (2000). Since parks provide a variety of benefits to the public that improve their quality of life, it is necessary to supply access to these benefits to ensure that cities are fair and just to their residents. The planner's role in providing park spaces must be to ensure that all groups of residents are supported equally as they strive to improve access and the quality of their park spaces.

It is the planner's aim to redistribute benefits within the city (Davidoff, 1978). This suggests that ensuring the benefits of parks are distributed equitably is a necessary role for park planners to fill. Park planners must seek to equalize the benefits of greenspace so that minorities, low income groups and other marginalized groups have access to parks that is equal to those groups that are not marginalized. Park planners can utilize tools for monitoring parks not only for their physical condition, but for the type of park users. This will provide data that will ensure parks are targeting all user needs and if not, planners will know that they have a challenge to resolve.

Throughout this review of park planning, it has become apparent that park spaces are essential components of city spaces that provide numerous benefits to the public, businesses and the local government. The history of park planning has led to the recognition of the need for equitable access to quality park spaces as a result of the wide variety of benefits that result from the presence of parks in cities. A number of concepts, designs, and trends have been touched on and provide context for the current research that is being conducted on monitoring quality park spaces in accordance with the Parks Plan in Toronto. It is important to note that park 
quality can only be maintained with the use of inspection programs that will ensure that city standards are being maintained. 


\subsection{Methodology}

\subsection{Overview}

The focus of this research is to evaluate the City's effectiveness in creating and maintaining quality park spaces in Toronto through the trial of a Park Report Card that focuses on basic amenities in parks in the densest wards. The model that is being applied is derived from New York City's Park Report Cards and their Parks Inspection Program (PIPs). A panel of park experts and community leaders from New York City defined the functional criteria that were used in NYC and those criteria will be used as the basis for this research design. A scoring system based on the relevant importance of each criterion or basic amenity was provided as well as features for evaluation (ie. cleanliness).

\subsection{Choosing the Sample}

The sample selection process was adapted from the NYC Park Report Card model as it is recognized as an effective model within North America. The NYC Park Report Card provides the public with an easy method to interpret the quality of their parks compared to others in the City. Toronto's PFAR department has used other initiatives that have been started in NYC, so it is a natural expansion to utilize this model.

The sample was chosen from parks in Toronto that are between 1 and 20 acres in area and located in the densest wards. The wards that are the densest are based on the City's ward profiles and the top 4 wards included were 14, 18, 20 and 27. These wards are located in the Old City of Toronto prior to amalgamation. The densest wards were chosen as the research is focused on parks in urban areas that are experiencing stresses caused by increased density. The parks within these wards were chosen based on the list and interactive map provided by PFAR on their website. The parks that had a size listed in the description that fell between 1 and 20 acres and located in the chosen wards were all included in the sample. Fourteen parks were chosen for site visits and analysis.

The sample will represent the parks in wards in Toronto that are experiencing the stresses of increased density, and will not be representative of the total park system. However, the results will be indicative of the application of park maintenance standards across the City. This sample was chosen and can be replicated in other municipalities experiencing density stresses. See Appendix $\mathrm{B}$ for a list of the parks chosen and the ward densities. 


\subsection{Choosing the Functional Criterion/Basic Amenities}

The basic amenities were chosen due to the ease of observation of their functionality and that they are all regularly present in parks in a standardized format. Ultimately, the amenities chosen for observation can be agreed upon as being necessary for the ease of use of parks for all users. Benches are vital to parks as they ensure that all users can enjoy the space with ease and for longer periods of time than just walking through them on the way to work for example. Passive greenspace provides relief from the City, which is related to a number of benefits that were outlined in the literature review, and this is why it is necessary to be observed. Water fountains encourage longer use in parks during summer months and were a central concern during the Parks Plan's (2013-2017) public consultations. Increasing the number of bathrooms and their overall cleanliness were also major concerns that were brought up during public consultations. Pathways are used daily by park users and may pose a risk for trips and falls if in disrepair. This made them an excellent basic amenity to observe for functionality to contribute to the overall park grades. All of the chosen basic amenities' evaluation criteria were adapted from the NYC Park Report which had used these same basic amenities as a means to evaluate the quality of parks.

Parks and the basic amenities were evaluated using a scoring method and checklist focusing on maintenance, cleanliness, safety and structural integrity that was developed based on NYC Report Cards and PIPs (Parks, 2013). For each criterion/basic amenity being evaluated, a total value was provided based on community input from NYC consultations that occurred during the development of the Report Card method. The scoring represents the value placed on that amenity in NYC, and it is assumed that it is equally applicable in a Toronto setting. The scoring can be viewed in Table 3 below.

Table 3: Basic Amenity Scores

\begin{tabular}{|l|l|}
\hline Basic Amenity & Score \\
\hline Passive greenspace & 5 \\
\hline Bathroom & 4 \\
\hline Drinking fountain & 3 \\
\hline Sitting areas & 5 \\
\hline Pathways & 3 \\
\hline Total & 20 \\
\hline
\end{tabular}


Each park being evaluated was visited once during the day in October 2013 over the course of a week. The basic amenities were observed and a value was given based on the interpretation of each score. Tables 4-8 provide the descriptions of each amenity's score. The tables ensure that each park is scored the same way and aids in preventing bias during data collection.

Table 4: Passive Greenspace

\begin{tabular}{|c|c|c|c|c|c|}
\hline Score & 1 & 2 & 3 & 4 & 5 \\
\hline Interpretation & $\begin{array}{l}\text { Lawns are } \\
\text { not } \\
\text { maintained. } \\
\text { A lot of dead } \\
\text { branches and } \\
\text { trees. } \\
\text { Greenspace } \\
\text { not useable } \\
\text { due to } \\
\text { amount of } \\
\text { litter. }\end{array}$ & $\begin{array}{l}\text { Some } \\
\text { maintenance } \\
\text { of lawns and } \\
\text { trees. A fair } \\
\text { bit of garbage } \\
\text { and litter. }\end{array}$ & $\begin{array}{l}\text { Lawns } \\
\text { require } \\
\text { mowing and } \\
\text { additional } \\
\text { maintenance. } \\
\text { Trees need } \\
\text { maintenance. } \\
\text { Garbage, } \\
\text { graffiti and } \\
\text { weeds } \\
\text { starting to } \\
\text { impact. }\end{array}$ & $\begin{array}{l}\text { Lawns are } \\
\text { slightly } \\
\text { overgrown. } \\
\text { No dead } \\
\text { trees but } \\
\text { some dead or } \\
\text { low lying } \\
\text { limbs. } \\
\text { Minimal } \\
\text { garbage, } \\
\text { graffiti and } \\
\text { weeds. }\end{array}$ & $\begin{array}{l}\text { Lawns are } \\
\text { properly } \\
\text { irrigated, } \\
\text { moved, even, } \\
\text { maintained. } \\
\text { Trees do not } \\
\text { have low } \\
\text { hanging } \\
\text { branches, no } \\
\text { dead limbs } \\
\text { and no dead } \\
\text { trees. } \\
\text { No litter, } \\
\text { graffiti or } \\
\text { weeds. }\end{array}$ \\
\hline
\end{tabular}

Table 5: Bathroom

\begin{tabular}{|l|l|l|l|l|}
\hline Score & 1 & 2 & 3 & 4 \\
\hline Interpretation & $\begin{array}{l}\text { Unusable due to } \\
\text { litter, graffiti and } \\
\text { lack of supplies }\end{array}$ & $\begin{array}{l}\text { Would rather not } \\
\text { use due to a fair } \\
\text { amount of litter } \\
\text { and graffiti and } \\
\text { minimal supplies }\end{array}$ & $\begin{array}{l}\text { Useable - clean } \\
\text { enough, some } \\
\text { litter or graffiti, } \\
\text { stocked with } \\
\text { supplies for the } \\
\text { day. }\end{array}$ & $\begin{array}{l}\text { Useable - clean, } \\
\text { no litter or graffiti } \\
\text { and fully stocked }\end{array}$ \\
\hline
\end{tabular}

Table 6: Water Fountain

\begin{tabular}{|l|l|l|l|}
\hline Score & 1 & 2 & 3 \\
\hline Interpretation & $\begin{array}{l}\text { Doesn't work and has } \\
\text { too much litter and } \\
\text { graffiti on it to use. }\end{array}$ & $\begin{array}{l}\text { Works but not the } \\
\text { most efficient. Some } \\
\text { litter and/or graffiti } \\
\text { that would detract } \\
\text { some users. }\end{array}$ & $\begin{array}{l}\text { Works well, no litter or } \\
\text { graffiti impeding use. }\end{array}$ \\
\hline
\end{tabular}


Table 7: Pathways

\begin{tabular}{|l|l|l|l|}
\hline Score & 1 & 2 & 3 \\
\hline Interpretation & $\begin{array}{l}\text { Holes, cracks and } \\
\text { protrusions in paved } \\
\text { pathways making } \\
\text { them unsafe. }\end{array}$ & $\begin{array}{l}\text { Some cracks in } \\
\text { pavement but no } \\
\text { major unevenness, so } \\
\text { they can still be used. }\end{array}$ & $\begin{array}{l}\text { New pathway that is } \\
\text { smooth and safe. }\end{array}$ \\
\hline
\end{tabular}

Table 8: Sitting Areas

\begin{tabular}{|c|c|c|c|c|c|}
\hline Score & 1 & 2 & 3 & 4 & 5 \\
\hline Interpretation & $\begin{array}{l}\text { User cannot sit } \\
\text { due to amount } \\
\text { of } \\
\text { garbage/graffiti } \\
\text { and/or level of } \\
\text { damage (ie. } \\
\text { missing slats) }\end{array}$ & $\begin{array}{l}\text { A fair amount } \\
\text { of } \\
\text { garbage/graffiti } \\
\text { with some } \\
\text { structural } \\
\text { damage that } \\
\text { reduces the } \\
\text { use greatly. }\end{array}$ & $\begin{array}{l}\text { Some graffiti } \\
\text { or garbage, } \\
\text { but seating } \\
\text { options still } \\
\text { available. } \\
\text { Some } \\
\text { structural } \\
\text { damage, but } \\
\text { seating can } \\
\text { still be used. }\end{array}$ & $\begin{array}{l}\text { Some graffiti } \\
\text { or garbage, } \\
\text { but seating } \\
\text { options still } \\
\text { available. } \\
\text { No structural } \\
\text { damage. } \\
\text { Can still be } \\
\text { used. }\end{array}$ & $\begin{array}{l}\text { No user } \\
\text { impact. } \\
\text { Clean, no } \\
\text { graffiti. No } \\
\text { structural } \\
\text { damage. }\end{array}$ \\
\hline
\end{tabular}

After each park's basic amenities were evaluated, a mark out of the total score will be calculated. From this, a numerical grade between $0-100$ is determined for each park by multiplying the total by 5 . The next step is a conversion from a numerical grade to a letter grade, which is based on the NYC conversion chart which is in Table 9. The conversion chart was determined through systematic consultations with the participating NYC community groups, local politicians and professionals within the field of park planning.

Table 9: Conversion Chart (NYC Park Report Cards, 2007)

\begin{tabular}{|l|l|}
\hline Numerical Grade & Letter Grade \\
\hline $97-100$ & A \\
\hline $93-96$ & A \\
\hline $90-92$ & A- \\
\hline $87-89$ & B + \\
\hline $83-86$ & B \\
\hline $80-82$ & B- \\
\hline $77-79$ & C+ \\
\hline $73-76$ & C \\
\hline $70-72$ & C- \\
\hline $60-69$ & D \\
\hline 59 and below & F \\
\hline
\end{tabular}

Analysis of the research provides knowledge of the current state of quality of Toronto's parks in the densest wards in the City. It can provide a baseline for the current status of parks and can 
be used to measure the City's progress in achieving quality park spaces as defined and outlined in the new Parks Plan.

\subsection{Summary of Steps:}

1. Background research is collected.

2. Identify functional park components/basic amenities to be evaluated.

3. Identify evaluation criteria.

4. Develop survey instrument based on PIPs.

5. Denote sample boundary.

6. Develop criterion for sample.

7. Identify sample.

8. Data collection and evaluation of parks using survey instrument.

9. Rank and score parks.

10. Calculate score out of 100 by multiplying totals by 5 and convert findings to letter grades.

11. Analyze data and state findings.

12. Provide recommendations.

A complete summary of the NYC Parks Inspection Program can be found in the Background section.

\subsection{Benefits}

There are numerous benefits to this research from the local neighbourhood level to the broader regional level. As the Greater Golden Horseshoe continues to become denser as stipulated in the Provincial Growth Plan, cities of varying sizes can use the findings from this research as a means to enhance their park planning and maintenance standards. Providing park report cards allows for comparisons within the City of Toronto and between cities. This will encourage high standards of park design and maintenance to enhance the quality and resulting benefits that parks provide across the region.

This research provides an easily understood translation of maintenance standards for the public. As a result, the public may be more encouraged to take a more active role in the maintenance and enhancement of their local parks. Higher degrees of ownership of local parks may lead to a more engaged public as they will be able to understand the quality standards attached to their park. Councilors in turn may recognize the growing importance of park spaces to their constituents and make park development, improvements and monitoring a higher 
political priority. Once parks are of higher priority on the political agenda, increased funding to enforce plans and policies may be secured.

Gaining more knowledge about the current state of parks has the potential to increase the awareness of the benefits that parks provide to the public, businesses and the local municipality. Gaining more awareness of the benefits derived from parks will encourage higher investment in them which in turn will improve the quality of life of residents.

\subsection{Limitations}

There are a variety of limitations that are observed in this research. The time frame is a major restraint in this research. Ideally the fieldwork research would have occurred over a longer time period allowing for comparisons of the ongoing maintenance of parks. Instead, due to the time constraints on the research, a baseline was provided of the parks surveyed. The time limitation made this more challenging to fully explore the feasibility of using the park report card method on an ongoing basis in Toronto. Alternatively, it can be evaluated on its ability to effectively report on current maintenance levels. Weather was another limiting factor which resulted in a single field observation session for each park.

There are limitations associated with not scoring all components in the parks that were observed. The unobserved factors in parks, such as active recreation fields and playground equipment, could have large influences on the quality of the park space. The data collected provided a score of the quality of each individual feature as well as that basic amenities influence of the overall quality of each park. There are also limitations attached to the sample size. A larger sample would have provided more data and possibly an improved understanding of the quality of parks that are in areas of high density.

When conducting the field observations, personal bias may occur when ranking the indicators of quality. The scoring matrix is the strongest counteraction to bias which is found in Tables 4-8. As well, there was only one researcher conducting the site visits which ensures that the bias is uniform and the data collected do not vary dramatically from one observation to another. If there were multiple field researchers, a variety of personal biases would be at play which may lead to variability in the findings.

A possible limitation is found in the difference between New York City and Toronto. Since the observation standards were developed in NYC, they may not be reflective of local values and opinions. Focus groups in Toronto would be required to develop City-specific scoring for each 
criterion/basic amenity identified by the public to be included in the check list for monitoring to counteract this possible drawback. A regional park planning report card survey tool would be ideal to record the intensity changes in park use as the Greater Golden Horseshoe continues to increase in density. 


\subsection{Findings and Analysis}

\subsection{Overall Findings}

Upon completion of the field research, the data were used to calculate the park report cards as outlined in the methodology. The results are summarized in Table 10 below. Appendix D provides the individual marks each basic amenity achieved, bench counts and bench to park size ratios. None of the surveyed parks achieved marks in the A range. There are a number of possible explanations for this occurrence which include, challenges with park maintenance and standards or funding is not available to meet the outlined standards in the Parks Plan. These possible explanations for the park findings will be explored in more depth. As well, the use of park report cards for benchmarking, evaluation and conveying information will be examined.

Table 10: Park Grades

\begin{tabular}{|l|l|}
\hline Park & Grade \\
\hline Alexandra Park & C \\
\hline Bellevue Park & B- \\
\hline Campbell Avenue Playground & D \\
\hline Canoe Landing & B- \\
\hline Dovercourt Park & B+ \\
\hline Dufferin Grove Park & C+ \\
\hline Grange Park & C \\
\hline Jesse Ketchum Park & D \\
\hline Little Norway Park & B \\
\hline MacGregor Park & B- \\
\hline Masaryk Park & B- \\
\hline McCormick Park & B- \\
\hline Moss Park & C \\
\hline Vermont Square & B- \\
\hline
\end{tabular}

The grades are reflective of parks throughout Toronto that are experiencing levels of stress resulting from increases in density. As the overall median of surveyed parks is a B-, the quality standard defined by the Parks Plan was not met on the day surveyed using the adapted park report card method. None of the parks were in the $A$ range, the majority were in the $B$ range and several parks received $C$ and $D$ grades. This range of marks is indicative of different usage levels and different lengths of time from the last visit by maintenance crews. A combination of basic amenities contributed to each park's scores and there was no specific feature that repeatedly had the lowest parks. However, passive greenspace never received the highest number of

marks that could be allotted. This may not be reflective of different maintenance standards because there are City-wide standards to ensure all park users have access to the same level of quality of basic park amenities.

The median grade is a B- which may indicate that parks in Toronto are experiencing pressures from density. The median grade would be higher if the observed basic amenities received 
higher individual marks which may reflect a higher quality of user experience in parks. The median grade should be higher to reflect the initiatives outlined in the Parks Plan. A mark of $A+$ would be reflective of parks that perfectly meet the outlined criteria of what defines a quality park. This should be the aim of park maintenance standards and should be reflected in the budget.

There are a variety of challenges that may be associated with the current park maintenance standards and the ability for Toronto parks to truly achieve marks that are reflective of the aims in the Parks Plan. Unfortunately, the standards are not released for public or academic scrutiny so it is difficult to pinpoint if the maintenance standards are the cause of the low grades. A possible reason for the lower marks is that the park maintenance standards may be too low across the City of Toronto. Park maintenance standards may be lower due to the transition between Summer and Fall standards which would explain the lower marks resulting from observations made in October. Alternatively, the standards may be consistently met; however, on the days that were observed, park maintenance crews may not have yet been present since their last visit. This would explain the lower grades received on the observed day, but it indicates that parks are maintained at too low a level to achieve grades that are reflective of the Parks Plan's goals. The standards could be acceptable; howevers the frequency of use in dense areas of the City may be underestimated resulting in lower marks. The median grade of a B- may reflect one specific issue or a combination of challenges.

The median grade and the lower grades overall may be reflective of the type of survey instrument that was used. The adaption of the NYC Park Report Card may be too strict resulting in the grades being lower. Because the tool and grading system was developed in NYC, the values and standards may not be reflective of Toronto's park standards. The low median grade may not be reflective of the quality of the park spaces, rather that the survey tool was not appropriately adapted to a different setting outside of NYC. The adapted park report card may not be an effective inspection method for reporting the level of quality of Toronto parks which may explain the low marks the parks received. The adaption of the park report card method may not have been effective because there are different maintenance standards and public expectations in NYC. The adaption of the NYC park report may have been too strict and not provided enough flexibility to include all features functionality and just focused on basic amenities. Therefore, the focus on basic amenities may have been too restrictive and not contributed to an appropriate adaption of the NYC Park Report Card method. For example, this method did not account for local preferences and different budget challenges that are 
experienced in Toronto. A more appropriate adaptation of the NYC Park Report Card may include more indicators and aesthetic features to help provide a more complete representation of Toronto's park spaces that may alter grades.

The parks may have received their lower marks because this research has focused on basic amenities and did not include aesthetic features. The surveyed basic amenities may not be a complete representation of the intent of the definition of quality as outlined by the City in the Parks Plan which would explain the lower grades. During the adaption of the NYC Park Report Card, aesthetic and other features were not included in this analysis as they tend to be arbitrary, potentially controversial and may produce bias. Aesthetic features may have a more positive effect on the park grades if they were included in the observations and provide a more complete representation of quality parks. Other park features can be evaluated for their functionality, such as playgrounds to increase the number of indicators included in the analysis. This will ensure that no one particular feature will have a drastic effect on the park grades.

The last reason that the grades may have been low may be reflective of the maintenance standards outlined in the Parks Plan not receiving enough funding. As the Quality of Parks initiative is unfunded according to the 2014 capital budget, this is a major indicator that park quality will not improve in 2014. The parks will continue to reflect the findings and grades from the observations in October 2013 since the Quality of Parks initiative is not being implemented at this time. 2013 service levels remain the same, and the baseline that the park grades provide will stay the same throughout 2014. As an unfunded mandate of the Parks Plan, the Quality of Parks initiative will have no effect in 2014 and will not change drastically until it is funded. The achieved grades represent pre-implementation of the Quality of Parks initiative of the Parks Plan and demonstrate that there is a need to improve the overall quality of basic amenities in parks in the densest wards of Toronto. Lack of funding for this initiative will see no alteration in the quality of Toronto parks despite increased number of users as Toronto's density increases.

This research has provided a benchmark or baseline mark for the parks surveyed representing the basic amenities of benches, passive greenspace, water fountains, bathrooms and pathways. These data can be used to compare parks and as a basis for improving the maintenance conducted, increasing the maintenance standards or even altering park design to achieve quality parks. Baselines are beneficial for research and ongoing maintenance to ensure that standards are being met and that parks can truly achieve quality standards once funding is obtained. Baselines or benchmarking can provide a means for comparison within a city or 
between cities (Daniels, 1996). The use of park report cards for benchmarking the City's park standards is effective as it is easily understood by the public and professionals as well.

The grades for each park are effective forms of communication for the public to understand the current status of their park's quality. Lower grades may lead the public to lobby their councilor to support the Parks Plan through funding or become involved in a 'Friends of' group. Each basic amenity contributes to the overall grades and funding for these specific features must be obtained. To better understand the current status of each basic amenity, more in depth analysis is provided below.

\section{Pathways}

The overall grades for pathways were fair, but can be improved as they are an integral part of making parks accessible. Pathways should always achieve the highest score as they ensure that there is equal access to park spaces for all users in dense areas, especially those who may have some mobility challenges, such as caretakers with baby strollers or seniors. Jesse Ketchum Park is an example of a poor score because the park did not have pathways. Only four of the fourteen parks achieved quality ranking on their pathways as they provided paths that were smooth and safe to navigate for all users. The remaining park spaces did not achieve quality rankings as they had cracks and were uneven, but not to the point of being unusable.

Parks tended to receive midrange marks for their pathways. Park quality was determined based on the ease of mobility of pedestrians. Cracking resulting from winter and ground shifting and leaves covering the paths were the main reasons for lost marks. Other aspects of mobility should be included in the pathway evaluation in the future including the ease of access for individuals with wheelchairs or strollers. For example, Dufferin Grove Park had a number of staircases throughout the park which reduce accessibility. The level of accessibility should be included within this standard or be a separate evaluation as it is important for the quality of park spaces. The current Parks Plan requires that PFAR meet all accessibility requirements when developing new parks and redeveloping existing parks.

Some parks may need redesigning to ensure that park users have safe pathways provided in maintained and manicured areas. Some pathways are not used as they do not follow the direction of user flow. This leads to degradation of passive greenspace unnecessarily. Park redesign can resolve this challenge and lead to quality pathways that follow the direction of user flow and improve the quality of passive greenspace. 


\section{Benches}

Sitting areas achieved the most consistent and highest rankings with nine of the fourteen observed parks attaining the best marks. The remaining parks had minor issues with the quality of seating with only a few examples of broken benches and the main cause of lost marks was the result of graffiti and garbage. To resolve this, more frequent graffiti removal and maintenance and/or higher maintenance standards need to be encouraged in parks located in high density neighbourhoods.

It was observed that there were too few benches in the parks that were visited during the research phase. Appendix $\mathrm{C}$ provides the number of benches for each park and the ratio of benches to park size. The number of benches in each park was divided by the size of each park to discover the number of benches per hectare which indicates that there are too few benches. This has the potential to reduce the use of park spaces and may negatively target demographic groups, such as seniors who may be more reliant on benches. Having an appropriate number of benches for park space that is reflective of surrounding environments is a necessary feature that must be explored by the City of Toronto as it will ensure inclusivity of all Toronto residents.

There currently is no standard provided to ensure that an appropriate number of benches are in each park. From observations, it was found that parks that had 20 or more benchers per hectare appeared to have an appropriate number of seating options without looking too crowded. Therefore 20 benches per hectare is recommended as a minimum bench standard that PFAR should achieve when they gain funding to fully implement the Parks Plan. All but 2 of the parks sampled met this recommendation. Vermont Square far exceeded the recommended minimum and provided 57 benches per hectare. Concerns that this would appear crowded are not the case as the design of the seating is unique. Approximately 30 benches are provided in a barrier that separates and encloses the playground from the rest of the park. Through unique and unobtrusive park design a large number of seating options can successfully be incorporated into parks. Therefore no maximum number of benches is suggested.

The City is currently working on a new plan to encourage social gathering places that has a central focus on providing an appropriate number of benches. This plan works in tandem with other basic amenities such as access to bathrooms and water fountains. There are objectives to increase the number of benches, but this is dependent upon capital budget approvals. 
Despite the Parks Plan aim to increase the number of benches to develop social gathering spaces, the 2014 budget has not provided any means for expanding on this initiative. Toronto has a bench donation system which is a method used to obtain additional seating in parks without being dependent upon yearly budget variations (PFAR, Commemorative Trees and Benches, 2014). This program, however, does not guarantee that the recommended minimum of 20 benches per hectare will be present in parks.

There were benches of different quality which can partially be attributed to the variety of styles. As part of the social gathering plan, a uniform bench type is being distributed to all parks as benches require replacing and new benches are being installed. Durability of bench materials must be central to this plan to ensure trouble-free maintenance and longevity of the seating. Quality park benches and increases in the number of benches to the recommended minimum will contribute to the quality of parks in Toronto. The City should target the parks in dense areas to ensure than an appropriate number of benches are provided.

\section{Passive Greenspace}

Passive greenspace consistently required more maintenance than was being provided to achieve marks that indicate quality park space. There was not a single park that had high quality greenspace as indicated by the determinants in Tables 4-8. Each park's greenspace received failing marks that resulted from poor maintenance of garbage, graffiti and/or dead tree branches.

This is a challenging basic amenity to evaluate as it is the largest and varies the most in quality. There tend to be sections of quality greenspace and sections that are less well-maintained. The approach used during the evaluation was to give the mark reflective of the worst sections of passive greenspace as it lessens the overall quality of a park.

The time of year of the observations highly impacts the quality of the passive greenspace. During the summer months, passive greenspace may achieve higher marks as a result of less moisture causing muddy grounds as people walk through. Higher maintenance standards in the summer would also result in lower levels of garbage being present. As well, there are strict grass lengths that the City maintains in an attempt to ensure that parks' passive greenspaces are equally and highly maintained. Therefore it is concluded that passive greenspace marks will fluctuate according to seasonality. 


\section{Water Fountains}

Every park that was visited had a drinking fountain, but only two of the fourteen parks analysed received complete marks for having quality fountains. With three parks receiving the worst weighting, the remaining 10 parks achieved average levels. This indicates that the majority of parks have functioning water fountains that have some garbage or graffiti that may reduce the visual quality and use of this park amenity. Since the social gathering space plans that are currently being developed rely on water fountains being present in park spaces, it is necessary to ensure that they are useable and maintained to a high standard. Water fountains contribute to the overall quality of parks and can easily contribute to parks achieving a top grade in neighbourhoods that are becoming denser.

\section{Bathrooms}

Of the fourteen parks analysed, only four parks had bathrooms. This is a natural constraint on the length of time that park users can stay in parks. Parks without bathrooms also reduce the likelihood of being used as destinations for social gatherings. PFAR does not have requirements stating that parks of a certain class or size require on-site bathroom access. It may be assumed that parks in dense urban areas of Toronto will have access to bathrooms in surrounding private establishments; however, this can still impact the level of use and quality of parks. Parks that have community centers may provide access for public use but this was not evaluated as part of this study. If there was no access to separate bathrooms outside of a community center, no marks were awarded because it was not part of the park report card method as adapted from NYC. It was determined that parks without bathrooms make visits more challenging for individuals who may have mobility difficulties because they will always have to leave the park to use a bathroom. This has a negative impact on the use of parks and the benefits that can be drawn from them. Providing bathrooms that are available for public use and are accessible will ensure that parks can be used as social a gathering space.

Resulting from the consultations that led to the development of the Parks Plan it was noted that the public wanted improved access to bathrooms within parks. Therefore parks need to be designed and redeveloped in a way that will encourage social gathering spaces and ensure that the public has access to bathrooms. The bathrooms that are built must be designed to be easy to clean and maintain to ensure that they contribute to the quality of the park space.

Of the parks that did have bathrooms, they were mostly closed as the plumbing needed to be shut off to prevent pipes from freezing during the time of year that the field research occurred. 
There were two bathrooms that were open to the public during the time that site visits were being conducted and they were well stocked and clean which contributed to those parks gaining higher marks. This may be reflective of the time of year and reduced use of outdoor space due

to temperature changes and more frequent inclement weather. During busier times, the cleanliness of the bathrooms may be reduced due to the intensity of use. Ongoing maintenance observations need to occur to explore the continuing quality and upkeep of the bathrooms that contribute to the overall quality of parks in densely populated cities.

\subsection{Application of Park Report Cards}

The use of park reports card in Toronto parks was easy to execute and can be conducted by maintenance staff or specially trained PFAR staff. This could occur in association with the park inspection program to create a legible and easily understood tool to measure the quality of parks based on the current park standards. The Parks Plan outlines plans to digitize the maintenance and repair component of the park inspection program to ensure that the process is easier and internally recorded. Combining the digitization of the parks inspection program and the introduction of a parks report card as the means of evaluation would be an aid to plan parks.

During observations, the specific evaluation of each park was easy to conduct as it required an analysis of the entire park space. This involved walking throughout the park and observing the space for the indicators in Tables 4-8. Quality park spaces are truly reflective of their basic amenities which became apparent during a time of year (October) that did not provide aesthetically pleasing surroundings. Park reports that focused on basic amenity space, however, are not reflective of the complete picture of park spaces. Park report cards should be broader and encompass a variety of features including general care of aesthetic features but are not an evaluation of the artistic nature of those features. Aesthetic components of parks are important features and could be included in the application of a park report card, but a means to avoid bias would need to be implemented. Ultimately, the functionality and maintenance level of all park features should be evaluated and included in park report cards to provide a greater understanding of the quality of park spaces.

Park report cards have the potential to increase the public awareness of the quality of parks within Toronto. The ease of legibility of a park grade may encourage locals to seek improvements to the quality of their parks if they repeatedly score poorly. The parks that achieved the lowest grades during this evaluation, such as Jesse Ketchum Park and Campbell Avenue Playground, could be improved by activism that may result from an understanding of 
the reduced quality of parks. Grades should be made public so residents could monitor the quality of their parks. Poor park quality could lead to resident's lobbying their councilors to ensure that appropriate funding is secured to implement the Quality of Park initiative of the Parks Plan. Park report cards have the potential to be used as a tool to engage political bodies to ensure that appropriate budget allocations are made to support the Parks Plan.

The application of park report cards in Toronto will be useful for knowing what parks need more frequent maintenance to ensure that quality parks are available for all residents. Park report cards can be incorporated into the parks inspection program that is being digitized which will increase the ease of access that the public has to this type of information. Public knowledge about the quality of local parks may encourage citizen participation in lobbying councilors to secure funding for the implementation of the Quality of Park initiative.

\subsection{Carrying Capacity}

The current amount of park and green space in Toronto is approximately 19,760 acres and the required amount of space needed to meet the standard provided by Charles Downing of 2 acres per 300 residents in cities over 1 million residents is calculated to be 17,433 acres (See Appendix C). This is reflective of the 2011 census data for the City of Toronto's population. Therefore the City has an appropriate amount of park and green space for its residents; however questions of quality and accessibility remain. The quality standards of basic amenities have been explored briefly in this research and it has found that there are basic amenities that require improvement since parks have not achieved high grades in Toronto's densest wards. Accessibility has not been a focus of this research, but is imperative in ensuring a high quality of life for all residents is achieved and maintained. A large proportion of the green space included in the total acreage is the ravine system which may not be easily accessible to all residents; further research can explore the accessibility of the ravines. City of Toronto does not provide statistics that distinguish between the area of greenspace that includes the ravine system and the area of greenspace that is representative of parks. Residents in dense urban areas must have access to green and park space as there are many outlined benefits to it that must be equally distributed. The City of Toronto must work to maintain the ratio of park and green space to residents at an acceptable standard especially within dense areas of the City.

City staff must ensure that there is enough park space for residents that do not have access to private green space and that the space is not being degraded by overuse. Utilizing a carrying capacity standard can resolve challenges of obtaining funding for parks as it is a quantitative 
indicator that can trigger demand for new park space otherwise park quality will decrease as a result of overuse. This calculation should use the total area of park space excluding the ravine system to have a more representative indicator. Alternatively, this calculation can be completed on a ward level, taking into account all publicly accessible greenspace, which can include the ravine system and privately owned public open spaces. A carrying capacity calculation should work in tandem with a park monitoring system such as a park report card as they both aim to maintain quality park space in cities experiencing density increases. This will aid City staff and Councilors in directing funding and lobbying for budget allocations to obtain new park land, to prevent degradation of existing park space and improve the quality of existing parks through design and maintenance standards. 


\subsection{Recommendations}

Upon analysis of the collected data a variety of recommendations are suggested for the City of Toronto's Parks, Forestry and Recreation Department that should be made central to their implementation of the Parks Plan to ensure that their initiative of Quality of Parks is achieved. The park report card method that was tested encountered a number of challenges in parks under strain from density and below are a series of recommendations to resolve them. Overall, the park report card method was effective and should be implemented at the same time as the digitization of the new parks inspection program occurs. Only one method is needed to inspect parks; however, the findings should be made public through the park report card format.

There are a number of recommendations for implementing a park report card method that build from the adapted trial of the NYC Park Report Card. It is important that the park report card be directly linked to Toronto's park maintenance standards which can be used as the basis for evaluating the quality of parks. Therefore, the methodology from the NYC Park Report Card can be used, but new weighting scales for each amenity being evaluated must be developed based on consultations in Toronto that would be conducted by PFAR and Community Planning together. This monitoring method must be implemented across the City to ensure that the maintenance standards are achieving quality parks equitably. Moving forward, funding through the 2015 operating budget is necessary to implement the park report card method as soon as possible. In the future, it is recommended that Council should only approve plans that will receive funding so they can be implemented fully.

From the field observations a number of recommendations for the basic amenities that were observed became apparent and needs to be implemented by PFAR. There is a need to include more criteria for each basic amenity being evaluated as well as new features being evaluated. The pathway indicator must not only focus on the maintenance and repairs of the physical structures, but also the modes of connecting the pathways such as ramps with handrails instead of stairs. Criteria focusing on accessibility must be included throughout the pathways evaluations. When evaluating benches and seating, there needs to be a criterion focusing on meeting a minimum of 20 benches per hectare. The city plans on implementing a uniform bench design; however, it was noted that creative designs, such as found in Vermont Square Park, can create lots of seating effectively. A balance must be achieved between restricting park design and ease of maintenance and repairs of benches. 
Despite the City being aware that it must improve the features and amenities in parks, it must be stressed again since it is of great importance to achieve quality parks. The following are two of the most apparent areas of improvement based on the field research conducted. Despite the large capital investment, there needs to be a greater number of bathrooms in parks to ensure that the public can use parks for longer periods of time. An increase in bathrooms can be triggered by the size of parks. As well, there is a need to explore options to increase the longevity of turf which will improve the quality of passive greenspace. During months when it is extremely wet, techniques to prevent degradation of the passive greenspace must be explored, such as putting up temporary barriers to restrict the public from walking off pathways. PFAR must work with the community to seek appropriate solutions to these challenges.

Since the City of Toronto has not released its maintenance standards in the past and their current standards are under review, it makes it impossible to truly evaluate them. Limited support from the City of Toronto has limited the scope of the analysis that has been completed regarding the current maintenance standards. Despite this, the method used to evaluate the parks clearly indicates that the parks are below the standard to meet the Quality of Parks initiative as defined in the Parks Plan. It is recommended that the maintenance standards need to be met to achieve quality park space and that PFAR should make the standards and results public to increase public awareness.

The Quality of Parks initiative that is presently unfunded according to the 2014 budget must receive funding as the park report grades are low and reflective of poor quality parks (PFAR, 2014 Operating Budget Highlights , 2014). This lack of implementation may have occurred for a variety of reasons; however, the quality of Toronto's parks in the densest wards is being negatively affected. The Quality of Parks initiative must be implemented to ensure that Toronto residents, businesses and the City reap the benefits that parks can provide. This initiative can be established City-wide through phasing that targets the densest areas first and then gradually is provided to less dense areas. This may seem unfair initially; however those individuals living in the densest parts of the City do not have access to private greenspace as readily as those individuals who live in single detached homes in lower density areas of the City. To ensure that improvements are being achieved, a park report card method should be implemented by PFAR so that the public can be aware of the true quality of their parks according to the City's standards. 


\subsection{Future Research}

Park planning research can be expanded in a variety of formats to continue to explore the value of quality park space and the techniques required to secure and achieve quality parks. This research can be completed again with variations, such as a larger sample, case studies of specific parks or comparing urban and suburban park quality. Potential findings may confirm the viability of applying park report cards as a park inspection method in cities that are becoming denser.

This research can be replicated using the same sample but the report card can be adapted to include more park features including aesthetic features which were originally excluded due to their arbitrariness. Aesthetic features can be included in future analysis as long as the functionality and maintenance of the feature is assessed. Precautions against bias must be taken to ensure that aesthetic features are not being evaluated based on personal preference.

The park report card is a method that can be replicated easily outside of Toronto and be applied to the Greater Golden Horseshoe Region given the provincially legislated growth. Comparing park report cards between cities has the potential to encourage a positive form of competition among cities using a standardized evaluation and report method. Cities can become known for having quality parks and residents within the Greater Golden Horseshoe would understand the ranking as it would be a consistent benchmarking tool across the region.

There are other benchmarking systems that can be tested in Toronto or the Greater Golden Horseshoe to guarantee comparability. PROGRAIS is an international benchmarking system from the National Recreation and Parks Association in the United States of America that ranks national parks. Applying a comparable approach can ensure comparisons of parks internationally. This would be beneficial to cities that are experiencing growth and density pressures as lessons can be learned from cities that consistently achieve high marks for quality park spaces.

Utilizing a monitoring system such as the park report card method can lead to improved community awareness and engagement as the public would seek to improve the quality of their local parks. Confirming that the public can comprehend the park report grades across different demographics and ethnic groups is a necessary area to explore to ensure that the park report card method can be used effectively to engage communities. Finding additional methods to engage the community to support park improvements can be the focus of future research. 
Ensuring that parks reflect the public's values and opinions is necessary so developing strategies to engage the public is necessary and would be a valuable form of future research.

Methods to improve the quality of park spaces outside of the municipal budget should be explored in the future. As there are limited municipal finances, partnerships with donors and 'Friends of' groups must be explored for their fundraising feasibility to improve local park spaces. Creative methods to secure funding that is directed at parks must be investigated and implemented to supplement the budget since there are a number of unfunded mandates in the Parks Plan. Ensuring that all mandates of the Parks Plan can be funded through a combination of funding tools should be the focus of future research.

Future research can focus on whether Toronto parks are meeting the needs of minority groups. Minority groups can include newcomers to the City, ethnic minorities, seniors, teenagers and other groups that historically have not been included when planning and designing park spaces. Basic amenity features and additional uses that are specific to welcoming minority groups must be included in parks to ensure that parks spaces are meeting everyone's needs.

An accessibility study of parks in Toronto should be conducted as the pathways did not achieve the highest ranking. Through park observations there were a number of barriers to individuals requiring assistance. For example, stairs and lack of ramps with support rails have the potential to negatively impact some users who require assistance. A study that focuses on the accessibility or the overall ease of use of parks spaces must be conducted to ensure that all residents can use parks safely. Features that improve ease of use such as benches must be properly studied in the future. Ongoing efforts to increase the number of benches in Toronto must be studied for their effectiveness as the number of benches is brought up to achieve the recommended minimum of 20 benches per hectare.

Exploring a viable carrying capacity calculation for park spaces will be valuable to future park planning as Toronto and other cities in the Greater Golden Horseshoe continue to become denser. A carrying capacity indicator would ensure that when parks are being overused, cities would need to limit development in that area until park space is obtained or alternative solutions are reached. It would also indicate park spaces where quality would be decreased as a result of over use. Therefore a park carrying capacity indicator that is specific to Toronto is necessary to ensure that quality park spaces are maintained and that all City residents have access to quality park spaces. This will also ensure that tourists can enjoy access to a variety of quality park spaces even in the densest urban areas of Toronto. 
As Toronto continues to experience density pressures, finding different forms of open space such as privately owned public spaces will become more prominent. San Francisco has completed an inventory of all privately owned public spaces and has placed plaques at each entrance. A comparable analysis of this work could be conducted in Toronto to ensure that Toronto residents and tourists would be able to utilize all available public spaces.

Park planning research can explore a variety of avenues. The most pertinent areas to study are the ones pertaining to the park improvements within Toronto to advance the quality of park spaces. Developing strategies, partnerships and implementation methods in areas of Toronto that are experiencing density pressures must be central to moving forward with the Parks Plan's (2013-2017) mandate to achieve quality parks. 


\section{Appendices}

\section{Appendix A - Toronto Park Categorization}

\begin{tabular}{|l|l|}
\hline Park Type & Description \\
\hline Parkette & $\begin{array}{l}\text { Less than } 0.5 \text { hectares. } \\
\text { Used by local residents for passive recreation. } \\
\text { Supplement and not replace larger park spaces. }\end{array}$ \\
\hline Neighbourhood park & $\begin{array}{l}\text { Generally not less than } 0.5 \text { hectares. } \\
\text { Used locally for both passive and some active recreation } \\
\text { purposes. }\end{array}$ \\
\hline Community park & $\begin{array}{l}\text { Generally not less than } 3 \text { hectares. } \\
\text { Serves several neighbourhoods. } \\
\text { Provides passive, active and programmed recreation. }\end{array}$ \\
\hline District park & $\begin{array}{l}\text { Generally not less than } 5 \text { hectares. } \\
\text { Serves several communities. } \\
\text { Higher levels of use, has parking when other smaller ones } \\
\text { do not. } \\
\text { Passive and active recreation; a hub for special functions } \\
\text { and programs. }\end{array}$ \\
\hline City park & $\begin{array}{l}\text { Serves users from across the city. } \\
\text { Generally not less than } 15 \text { hectares. } \\
\text { Destination for tourists. } \\
\text { Can contain natural or cultural heritage features. } \\
\text { le. Woodbine Beach. }\end{array}$ \\
\hline
\end{tabular}

Note: Descriptions provided from the Parks Plan. 


\section{Appendix B - Park Sample and Ward Densities}

\begin{tabular}{|c|c|c|c|c|c|}
\hline Park Name & Ward & Address & Size(ha) & Size(acres) & Description \\
\hline $\begin{array}{l}\text { Masaryk } \\
\text { Park }\end{array}$ & 14 & $\begin{array}{l}212 \text { Cowan } \\
\text { Ave }\end{array}$ & 0.5 & 1.235 & $\begin{array}{l}\text { Community garden, wading } \\
\text { pool, playground. }\end{array}$ \\
\hline $\begin{array}{l}\text { Campbell } \\
\text { Avenue } \\
\text { Playground }\end{array}$ & 18 & $\begin{array}{l}255 \\
\text { Campbell } \\
\text { Ave }\end{array}$ & 1.3 & 3.211 & $\begin{array}{l}\text { Three sports fields, wading } \\
\text { pool, basketball court and } \\
\text { playground. }\end{array}$ \\
\hline $\begin{array}{l}\text { MacGregor } \\
\text { Playground }\end{array}$ & 18 & $\begin{array}{l}346 \\
\text { Lansdowne } \\
\text { Ave }\end{array}$ & 1.4 & 3.458 & $\begin{array}{l}\text { Lighted ball diamond, a field } \\
\text { house, a basketball court, a } \\
\text { wading pool and a children's } \\
\text { playground. }\end{array}$ \\
\hline $\begin{array}{l}\text { McCormick } \\
\text { Park }\end{array}$ & 18 & $\begin{array}{l}66 \text { Sheridan } \\
\text { Ave }\end{array}$ & 1.5 & 3.705 & $\begin{array}{l}\text { A ball diamond, two basketball } \\
\text { courts, a wading pool and a } \\
\text { children's playground. }\end{array}$ \\
\hline $\begin{array}{l}\text { Dufferin } \\
\text { Grove Park }\end{array}$ & 18 & $\begin{array}{l}875 \text { Dufferin } \\
\text { St }\end{array}$ & 5.3 & 13.091 & $\begin{array}{l}\text { Large mature forest canopy. } \\
\text { The park features a multi- } \\
\text { purpose sports field, a } \\
\text { basketball court, a picnic area, } \\
\text { a wading pool and a children's } \\
\text { playground and artificial ice } \\
\text { rink. }\end{array}$ \\
\hline $\begin{array}{l}\text { Dovercourt } \\
\text { Park }\end{array}$ & 18 & $\begin{array}{l}155 \text { Bartlett } \\
\text { Ave }\end{array}$ & 2.4 & 5.928 & $\begin{array}{l}\text { Lighted ball diamond, wading } \\
\text { pool, two tennis courts and } \\
\text { playground and has street } \\
\text { parking around outskirts. }\end{array}$ \\
\hline $\begin{array}{l}\text { Vermont } \\
\text { Square }\end{array}$ & 20 & $\begin{array}{l}819 \\
\text { Palmerston } \\
\text { Ave }\end{array}$ & 1.5 & 3.705 & No description. \\
\hline $\begin{array}{l}\text { Bellevue } \\
\text { Park }\end{array}$ & 20 & $\begin{array}{l}5 \text { Bellevue } \\
\text { Ave }\end{array}$ & 0.49 & 1.2103 & $\begin{array}{l}\text { Wading pool, playground and } \\
\text { water fountain. }\end{array}$ \\
\hline $\begin{array}{l}\text { Alexandra } \\
\text { Park }\end{array}$ & 20 & $\begin{array}{l}275 \\
\text { Bathurst }\end{array}$ & 2.7 & 6.669 & $\begin{array}{l}\text { Featuring a children's } \\
\text { playground, community } \\
\text { garden, volleyball court. } \\
\text { Located at Scadding Court. }\end{array}$ \\
\hline $\begin{array}{l}\text { Grange } \\
\text { Park }\end{array}$ & 20 & $\begin{array}{l}317 \text { Dundas } \\
\text { St W }\end{array}$ & 1.8 & 4.446 & $\begin{array}{l}\text { Owned by AGO but run my } \\
\text { PFAR. }\end{array}$ \\
\hline $\begin{array}{l}\text { Canoe } \\
\text { Landing }\end{array}$ & 20 & $\begin{array}{l}95 \text { Fort York } \\
\text { Blvd }\end{array}$ & 3.1 & 7.657 & $\begin{array}{l}\text { Walking paths and } \\
\text { multipurpose sports fields. }\end{array}$ \\
\hline $\begin{array}{l}\text { Little } \\
\text { Norway } \\
\text { Park }\end{array}$ & 20 & $\begin{array}{l}659 \text { Queens } \\
\text { Quay }\end{array}$ & 2.4 & 5.928 & $\begin{array}{l}\text { Ball diamond, wading pool, } \\
\text { children's playground and } \\
\text { walking paths. }\end{array}$ \\
\hline Moss Park & 27 & $\begin{array}{l}150 \\
\text { Sherbourne } \\
\text { St }\end{array}$ & 3.4 & 8.398 & $\begin{array}{l}\text { A lighted ball diamond, two } \\
\text { tennis courts, a basket ball } \\
\text { court, a wading pool and a } \\
\text { children`s playground. }\end{array}$ \\
\hline $\begin{array}{l}\text { Jesse } \\
\text { Ketchum } \\
\text { Park }\end{array}$ & 27 & 1310 Bay St & 1.2 & 2.964 & Mature tree canopy. \\
\hline
\end{tabular}

Note: Descriptions are based on descriptions from the PFAR website. 


\begin{tabular}{|r|r|}
\hline Ward & $\begin{array}{l}\text { Density (thousand } \\
\text { people } / \mathrm{km}^{2} \text { ) }\end{array}$ \\
\hline 14 & 9.93 \\
\hline 18 & 9.49 \\
\hline 20 & 10.27 \\
\hline 27 & 9.49 \\
\hline
\end{tabular}




\section{Appendix C - Carrying Capacity}

Total Toronto Park

Hectares

8000

Acres

19760

Total Toronto Population (2011 Census)

2615060

Carrying Capacity

Standard for Cities over 1 million residents $=2$ acres $/ 300$ residents

17433.7

\section{Appendix D}

\begin{tabular}{|l|r|l|r|r|}
\hline Parks & Passive Greenspace & Bathroom & Drinking Fountains & Pathways \\
\hline Masaryk Park & 4 & N/A & 3 & 2 \\
Campell Avenue Playground & 4 & N/A & 1 & 2 \\
MacGregor Playground & 4 & locked & 2 & 2 \\
McCormick Park & 4 & N/A & 2 & 2 \\
Dufferin Grove Park & 4 & locked & 2 & 2 \\
Dovercourt Park & 4 & N/A & 3 & 3 \\
Vermont Square & 4 & N/A & 2 & 2 \\
Bellevue Park & 3 & N/A & 2 & 3 \\
Alexandra Park & 4 & N/A & 2 & 3 \\
Grange Park & 4 & locked & 1 & 2 \\
Canoe Landing & 3 & N/A & 2 & 3 \\
Little Norway Park & 4 & & 4 & 2 \\
Moss Park & 3 & N/A & 2 \\
Jesse Ketchum Park & 3 & N/A & 2 \\
\hline
\end{tabular}

Note: There were no man made pathways in Jesse

Ketchum Park.

Note: In the locations that had bathrooms, tended to be closed as a result of seasonality.

* There is a a wall divider between the playground and passive greenspace that provides 50 additional seats in Vermont Square. 


\begin{tabular}{|c|c|c|c|c|c|}
\hline Sitting Areas & Numerical Grade & Letter Grade & Number of Benches & Benches/Hectare & Park Size(ha) \\
\hline 4 & $81 \%$ & B- & 5 & 10.0 & 0.5 \\
\hline 4 & $69 \%$ & $D$ & 14 & 10.8 & 1.3 \\
\hline 5 & $81 \%$ & B- & 10 & 7.1 & 1.4 \\
\hline 5 & $81 \%$ & B- & 15 & 10.0 & 1.5 \\
\hline 4 & $77 \%$ & $\mathrm{C}+$ & 9 & 17.2 & 5.3 \\
\hline 4 & $88 \%$ & $\mathrm{~B}+$ & 17 & 7.1 & 2.4 \\
\hline 5 & $81 \%$ & B- & $86^{\star}$ & 57.3 & 1.5 \\
\hline 5 & $81 \%$ & B- & 7 & 14.3 & 0.49 \\
\hline 3 & $75 \%$ & $c$ & 25 & 9.3 & 2.7 \\
\hline 5 & $75 \%$ & c & 42 & 23.3 & 1.8 \\
\hline 5 & $81 \%$ & B- & 50 & 16.1 & 3.1 \\
\hline 5 & $85 \%$ & $B+$ & 34 & 14.2 & 2.4 \\
\hline 5 & $75 \%$ & c & 17 & 5.0 & 3.4 \\
\hline 5 & $69 \%$ & $D$ & 1 & 0.8 & 1.2 \\
\hline
\end{tabular}




\section{Works Cited}

Association, N. R. (2010). Synopsis of 2010 Research Papers. United States: National Recreation and Parks Association.

Barrow, G. Y. (1979). Zonation and Carrying Capactiy Estimates in Canadian Park Planning. England: Applied Science Publishers.

Boland, G. C. (2004). Defining the Sustainable Park: A Fifth Model for Urban Parks. Landscape Journal , 102-120.

Canada, S. (2011). Census Profile. Retrieved February 3, 2014, from Statistics Canada: http://www12.statcan.gc.ca/census-recensement/2011/dp$\mathrm{pd} /$ prof/details/page.cfm?Lang=E\&Geo1=CSD\&Code1=3520005\&Geo2=PR\&Code2=35\&Data= Count\&SearchText=Toronto\&SearchType=Begins \&SearchPR=01\&B1=All\&GeoLevel=PR\&Geo Code $=3520005$

Chen, C. J. (2003). Comprehensive greenspace planning based on landscape ecology principles in compact Nanjing city, China. Landscape and Urban Planning , 1-22.

(1998). Chicago City Space Plan. Chicago: City of Chicago.

Christiansen, M. L. (1977). Park Planning Handbook. Canada: John Wiley \& Sons Inc.

CMAP. (n.d.). Retrieved March 3, 2013, from Chicago Metropolitan Agency for Planning: http://www.cmap.illinois.gov/

CMAP. (2010). Go To 2040. Chicago: Chicago Metropolitan Agency for Planning.

Committee, E. D. (2004). Toronto Parks and Recreation Strategic Plan Our Common Ground. Toronto: City of Toronto.

Costa, A. K. (2011). Planning of Recreation Parks in the University Campus. Journal of Environment Protection , 365-370.

Crawford, A. W. (1910). City Planning and Philadelphia Parks. Annals of the American Academy of Political and Social Science, 71-80.

Crompton, J. (2001). The Impact of Parks on Property Values: A Review of the Empircal Evidence. Journal of Leisure Research , 1-33.

Daniels, S. (1996). Benchmarking. Emerald , 18-20.

Davidoff, P. (1965). Advocacy and Pluralism in Planning. Journal of the American Institute of Planners , 331 - 338.

Davidoff, P. (1978). The redistributive function of planning: Creating greater equity among citizens of communities. In R. B. Sternlieb, Planning Theory in the 1980s (pp. 69-72). New Jersey: Rutgers University. 
Deakin, E. (1999). Social Equity in Planning. Berkeley Planning Journal , 1-5.

(2010). Development of a City-wide Parks Plan. Toronto: City of Toronto.

DiPalermo, C. (2007). The Report Card on Parks 2007. New York City: New Yorkers for Parks.

Fainstein, S. S. (2000). New Directions in Planning Theory. Urban Affairs Review , 451-478.

Francis, M. (1987). Some different meanings atached to a city park and community gardens. Landscape Journal , 101-112.

Frumkin, H. (2003). Healthy Places: Exploring the Evidence. American Jounal of Public Health, 1451-1456.

Geoffrey C. Godbey, L. L. (2005). Contributions of Leisure Studies and Recreation and Park Management Research to the Active Living Agenda. American Journal of Preventive Medicine, 150-159.

Gobster, P. (2001). Visions of nature: conflict and compatibility in urban park restoration. Landscape and Urban Planning , 35-51.

(2006). Greenspace Master Plan. Ottawa: Ottawa.

Hartig, T. (2004). Restorative Environments. In C. Spielberger, Encyclopedia of Applied Psychology (pp. 273-279). San Diego: Academic Press.

Harvey, D. (2010). Fertile Ground for New Thinking: Improving Toronto's Parks. Toronto: Metcalf Foundation.

Hendon, J. K. (1967). Land Values Adjacent to an Urban Neighbourhood Park. Land Economics , 357-360.

Highline, F. o. (2013). The Highline. Retrieved September 26, 2013, from The Highline: http://www.thehighline.org/

Infrastructure, M. o. (2013, February 13). Places to Grow. Retrieved November 4, 2013, from https://www.placestogrow.ca/index.php

Kevin Thwaites, I. S. (2010). Towards socially restorative urbanism: exploring social and spatial implications for urban restorative experience. Landscape Review , 26-39.

Loukaitou-Sideris, A. (1995). Urban Form and Social Context: Cultural Differentiation in the Uses of Urban Parks. Journal of Planning Education and Research, 89-102.

Mattocks, R. H. (1937). Park Planning: Part II. The Town Review , 243-270.

Menendez, S. d. (2005). Estimating the non-market benefits of an urban park: Does proximity matter? Land Use Policy , 1-10. 
Merriam-Webster. (2014). Benchmark. Retrieved March 15, 2014, from Merriam-Webster: http://www.merriam-webster.com/dictionary/benchmark

Michaels, S. (2014). Urban HEART @ Toronto.Toronto: Toronto Community Health Profiles Partnership.

Moeller, J. (1965). Standards for Outdoor Recreational Areas. American Society of Planning Officials.

Olshansky, R. (2003). Planning for Public Parks. Journal of the American Planning Association, 318.

Ontario. (2006). Growth Plan for the Greater Golden Horseshoe. Ministry of Infrastructure.

Parks, C. S. (2005). Park and Recreation Trends in California. California: National Park Service.

Parks, N. (2013). Parks Inspection Program. Retrieved January 14, 2013, from NYC Parks: http://www.nycgovparks.org/park-features/parks-inspection-program

Parks, N. Y. (2013). Report Cards. Retrieved September 20, 2013, from New Yorkers for Parks: http://www.ny4p.org/research/report-cards

Peterson, G. (1993). Parks and Recreation: Fundamental for this City. Parks and Recreation, 48-51.

PFAR. (2014). 2014 Budget at a Glance. Toronto: City of Toronto.

PFAR. (2014). 2014 Operating Budget Highlights . Retrieved February 4, 2014, from Parks, Forestry \& Recreation :

http://www1.toronto.ca/wps/portal/contentonly?vgnextoid=a2a68d5c19c52410VgnVCM1000007 1d60f89RCRD\&vgnextfmt=default

PFAR. (2014). Commemorative Trees and Benches. Retrieved January 31, 2014, from City of Toronto:

https://www1.toronto.ca/wps/portal/contentonly?vgnextoid=b7a1ede252801410VgnVCM100000 71d60f89RCRD\&vgnextchannel=470bdada600f0410VgnVCM10000071d60f89RCRD

PFAR. (2013). Staff report for action on the Parks Plan. Toronto: Toronto.

PFAR. (2014). Toronto 2014 Budget. Toronto: City of Toronto.

PFAR. (2013). Toronto's geography. Retrieved February 3, 2014, from City of Toronto: http://www.toronto.ca/toronto_facts/geography.htm

Rutledge, A. J. (1971). Anatomy of a Park. New York City: McGraw-Hill, Inc.

Schanuel, A. P. (2005). The Economics of Urban Park Planning. Park \& Recreation , 64-67. 
Stephen Page, K. N. (1994). Managing Urban Parks: User Perspectives and Local Leisure Needs in the 1990s. The Service Industries Journal , 216-238.

T. Hartig, M. M. (1991). Restorative Effects of Natural Environment Experiences. Environment and Behaviour , 3-26.

Timmermans, A. K. (2006). Heterogeneity in Urban Park Use of Aging Visitors: A Latent Class Analysis. Greenspace Project, 1-15.

(2010). Toronto Official Plan. Toronto: City of Toronto.

Toronto. (2013). Parks Plan Summary. Toronto: Toronto.

TRCA. (2013). The Living City Policies. Retrieved January 14, 2013, from Toronto and Region Conservation Authority: http://trca.on.ca/the-living-city/public-consultations/the-living-citypolicies.dot

Ulrich, R. (1979). Visual Landscapes and Psychological Well-being. Landscape Research, 1723. 